\title{
Carbon in the Convecting Mantle
}

\author{
ERIK H. HAURI, ELIZABETH COTTRELL, KATHERINE A. KELLEY, \\ JONATHAN M. TUCKER, KEI SHIMIZU, MARION LE VOYER, \\ JARED MARSKE, AND ALBERTO E. SAAL
}

\subsection{Introduction}

The flux of magmatic $\mathrm{CO}_{2}$ into the oceans and atmosphere contributes to the global surface carbon cycle, and changes in basaltic magma production and associated degassing have been proposed as one of several important forcing mechanisms that have influenced past global climate variations. ${ }^{1-4}$ Despite this degassing, the vast majority of Earth's carbon is present not at the surface but in Earth's convecting mantle. ${ }^{5-10}$ The convecting mantle is the part of the mantle that lies beneath tectonic plates, and its motions over geologic timescales are driven by the sinking of cold oceanic plates into the interior and hot active upwellings originating from great depth. The convecting upper mantle rises, melts, and erupts mid-ocean ridge basalt (MORB) due to seafloor spreading along the $56,000-\mathrm{km}$ length of the global mid-ocean ridge system. Active upwellings, driven by mantle buoyancy, produce intraplate and near-ridge hot spots (e.g. Hawaii, Iceland) that erupt ocean island basalt (OIB) with a smaller overall flux. ${ }^{11}$ Occasionally, however, active upwellings produce large igneous provinces (LIPs; e.g. Ontong-Java Plateau, Caribbean-Columbian Plateau, Manihiki Plateau, Kerguelen Plateau) characterized by enormous outputs of magma erupted over very short timescales. These flood basalt eruptions have often coincided in time with global climate crises and mass species extinctions. ${ }^{12-16}$ Ridges, hot spots, and LIPs represent the main volcanic expressions of the delivery of heat to Earth's surface by the ongoing motions of the convecting mantle.

Seafloor dredging and core recovery have produced tens of thousands of individual submarine glass and rock samples. Study of these samples has demonstrated that variations in the major and trace element chemistry of MORBs and OIBs are primarily the result of crystal fractionation following polybaric melting of mantle sources at different depths and variable temperatures. ${ }^{17-21}$ At the same time, isotopic differences between MORBs and OIBs show that the mantle sources of hot spots are much more diverse and heterogeneous than those of ridges, reflecting their derivation from distinct reservoirs within the convecting mantle consisting of numerous geochemically distinct components with varied origins and evolutions. ${ }^{2-25}$ Some of these reservoirs have retained anomalies in short-lived isotope systems that were active only in the first tens of millions of years of Earth's 
history, and thus appear to have been isolated from each other - and from Earth's surface for a large fraction of the age of Earth. ${ }^{26-33}$ It is also well established that, from segment to segment, the concentrations of highly incompatible trace elements do not correlate with crustal thickness (a proxy for potential temperature) or spreading rate (a proxy for melting dynamics). Instead, highly incompatible trace elements (e.g. Th concentrations, $\mathrm{Ba} / \mathrm{Nb}$ ratios) covary with radiogenic isotopes (e.g. ${ }^{87} \mathrm{Sr} /{ }^{86} \mathrm{Sr}$ ) within segments, ${ }^{34}$ approaching hot spots, ${ }^{35}$ and globally; ${ }^{36}$ these covariations indicate heterogeneity in the mantle source. Here, we rely on this fundamental observation of MORB and OIB geochemistry to infer mantle carbon concentrations (Section 9.3.2).

Carbon is a trace element in the mantle, and it is present in erupted magmas as $\mathrm{CO}_{2}$-rich vesicles and as carbonate ions dissolved in the melt. ${ }^{37,38}$ The solubility of $\mathrm{CO}_{2}$ in basaltic magma is low at pressures of eruption on land or on the seafloor, ${ }^{39-42}$ and as a result nearly all magmas have degassed much of their original pre-eruptive budget of carbon during eruption. Degassing has thus complicated the use of MORBs and OIBs for determining the carbon content of their mantle sources and the flux of $\mathrm{CO}_{2}$ from basaltic eruptions. To attempt to circumvent this complication, researchers have used a variety of microbeam analysis methods to study the composition and volatile content of melt inclusions, which are small pockets of melt (tens to hundreds of microns in diameter) that become trapped in phenocryst minerals that grow in the magma prior to eruption at the surface (Figure 9.1) and are consequently less degassed than their host magmas. Fourier-transform infrared spectroscopy (FTIR) and secondary ion mass spectrometery (SIMS) have both been used to make accurate and precise measurements of $\mathrm{CO}_{2}$ and $\mathrm{H}_{2} \mathrm{O}$ in melt inclusions, providing a means to interrogate collections of MORB and OIB samples to study the origin and evolution of carbon in the convecting mantle. Most melt inclusions (with some exceptions; see below) contain a vapor bubble formed at vapor saturation after inclusion entrapment, during differential cooling of the melt inside the olivine crystals (Figure 9.1). These vapor bubbles typically contain most of the $\mathrm{CO}_{2}$ within the inclusion, but they cannot be measured by SIMS or FTIR. ${ }^{43,44}$

In this chapter, we review the types of samples that are best studied to assessing the primary $\mathrm{CO}_{2}$ content of magmas from mid-ocean ridges and hot spots, estimate volcanic fluxes, and estimate the $\mathrm{CO}_{2}$ content of mantle sources present in the convecting mantle. While we are unable to assess the primary $\mathrm{CO}_{2}$ content of LIP magmas, we review $\mathrm{CO}_{2}$ flux estimates from the literature. The volcanism that we consider here does not include subduction zones or continental intraplate volcanism, which are covered in Chapter 8. We also do not consider petit-spot volcanism - small, young edifices discovered outboard of the Japan trench. ${ }^{45}$ These lavas may originate from below the lithosphere-asthenosphere boundary and erupt on the seafloor due to plate flexure. They are highly alkalic and highly vesicular, such that they may carry significant $\mathrm{CO}_{2}$, although it is unclear whether this $\mathrm{CO}_{2}$ originated from the mantle or from crustal contamination. Their occurrence may be restricted to a few edifices outboard of the Japan trench, or could be ubiquitous. Their contribution to $\mathrm{CO}_{2}$ outgassing is presently highly unconstrained. 


\section{Carbon Dioxide and Non-Volatile Trace Element Behavior in Magmas at Oceanic Volcanoes}

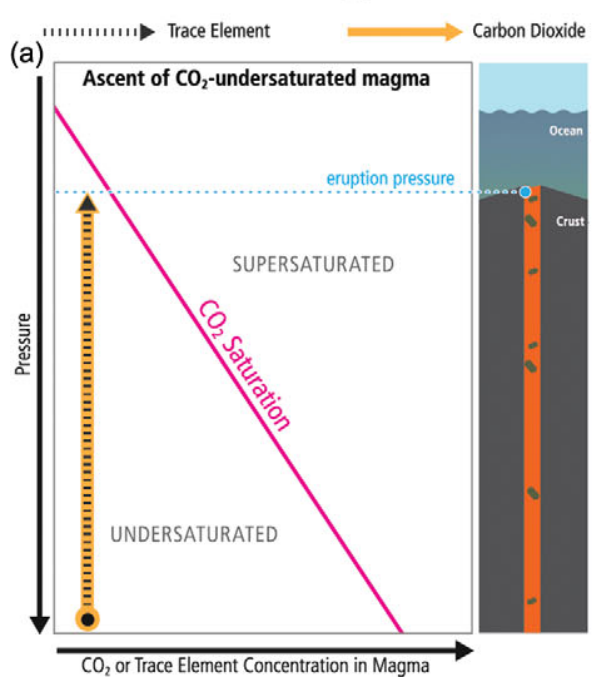

(b)

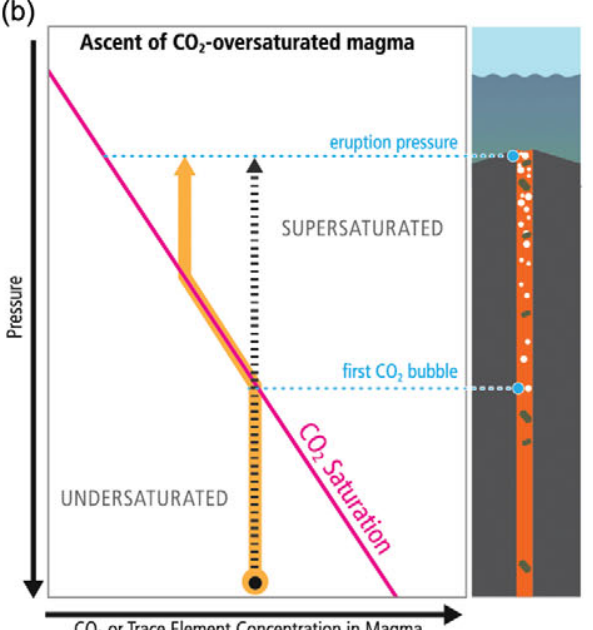

$\mathrm{CO}_{2}$ or Trace Element Concentration in Magma

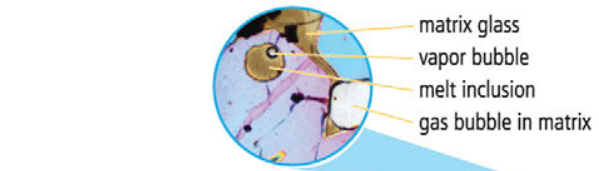

(c)

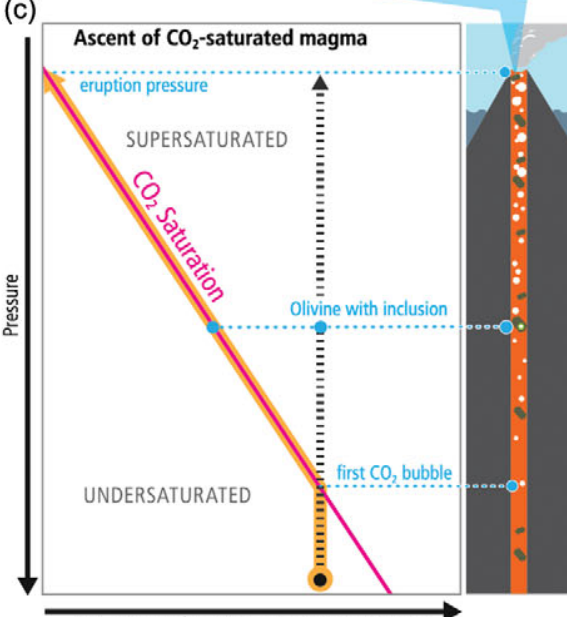

$\mathrm{CO}_{2}$ or Trace Element Concentration in Magma

Figure 9.1 Illustration of carbon dioxide and nonvolatile trace element behavior in magmas at oceanic volcanoes. Each panel tracks the concentration of $\mathrm{CO}_{2}$ and a nonvolatile trace element during the ascent of magma for three hypothetical cases. (a) $\mathrm{A} \mathrm{CO}_{2}$-undersaturated magma that begins with low volatile and trace element concentrations. In this case, the magma ascends and erupts on the seafloor without experiencing $\mathrm{CO}_{2}$ degassing, such that the starting $\mathrm{CO}_{2}$ concentration and that of a nonvolatile trace element remain roughly constant during ascent and eruption. (b) A magma that begins with higher volatile and trace element concentrations and experiences $\mathrm{CO}_{2}$ saturation during ascent to the seafloor. At conditions of saturation, bubbles form as the magma moves upwards to lower pressure, removing $\mathrm{CO}_{2}$ from the magma. The concentration of a nonvolatile trace element in this system, however, remains roughly constant. In the last stages prior to eruption, the magma may move faster than $\mathrm{CO}_{2}$ is able to diffuse toward bubbles, resulting in an erupted magma on the seafloor that contains more $\mathrm{CO}_{2}$ than would be present for equilibrium saturation (i.e. it is supersaturated). This is the most common condition for basalts erupted at mid-ocean ridges. (c) A volatile- and trace element-enriched magma that ascends beneath an oceanic island and experiences $\mathrm{CO}_{2}$ saturation at greater depth. Because of the lower eruption pressure above sea level, the magma loses virtually all of its $\mathrm{CO}_{2}$ to degassing, whereas the concentration of a nonvolatile trace element remains roughly constant. In all cases, olivine-hosted melt inclusions (see inset, sample NMNH 116111-5 melt inclusion is $100 \mu \mathrm{m}$ in diameter) may trap melts during various stages of ascent. If trapped at pressures higher than the $\mathrm{CO}_{2}$ saturation curve, melt inclusions may preserve the undegassed magma composition even if the external magma has experienced degassing. 


\subsection{Sampling}

Major collections of seafloor samples (Figure 9.2) are discoverable and searchable through the Index to Marine and Lacustrine Geological Samples (IMLGS) at the National Centers for Environmental Information (NCEI; formerly National Geophysical Data Center, NGDC) at the US National Oceanographic and Atmospheric Association. ${ }^{46}$ Once identified, samples can be requested from the individual sample repositories. In this chapter, we rely heavily on the MORB study of Le Voyer et al. ${ }^{47}$ (and references therein), who reported new data on 753 geographically distributed MORB samples, combined with a qualitycontrolled database of published data from an additional 2446 samples, describing $\mathrm{CO}_{2}$ fluxes and estimated primary magma $\mathrm{CO}_{2}$ contents for 387 of the 458 mid-ocean ridge segments with major element data (out of a total of 711 geophysically defined MORB ridge segments). ${ }^{17,36}$ Among these MORB samples, there exist samples with sufficiently low pre-eruptive carbon contents and high eruptive pressures that they are thought to have avoided $\mathrm{CO}_{2}$ degassing (e.g. Figure 9.1a); these samples display correlations of $\mathrm{CO}_{2}$ with nonvolatile trace elements, as described by Cartigny et al. ${ }^{48}$ and Javoy and Pineau ${ }^{38}\left(\mathrm{CO}_{2^{-}}\right.$ rich samples), and by Saal et al., ${ }^{49}$ Michael and Graham ${ }^{50}$, and Shimizu et al. ${ }^{51}$ (undegassed samples; Figure 9.3). Additionally, three suites of melt inclusions from MORB sources show similar correlations of $\mathrm{CO}_{2}$ with nonvolatile trace elements characteristic of vapor undersaturation, which have been described from the Siqueiros Transform on the East Pacific Rise, ${ }^{49}$ the equatorial Mid-Atlantic Ridge, ${ }^{52}$ and northern Iceland (Figure 9.3) ${ }^{53}$ Importantly, these three melt inclusion suites are dominated by inclusions that have not formed post-entrapment vapor bubbles, such that the pre-eruptive magmatic $\mathrm{CO}_{2}$ contents are preserved in the glass. These data are supplemented by an additional 113 melt inclusions that have been measured for $\mathrm{CO}_{2}$ but show evidence of degassing; these come from the Gakkel Ridge, ${ }^{54,55}$ the Juan de Fuca Ridge, ${ }^{56}$ the Lucky Strike segment of the Mid-Atlantic Ridge, ${ }^{57}$ and selected melt inclusions from Axial Seamount on the Juan de Fuca Ridge. ${ }^{58}$ This entire set of new and published data, from the paper of Le Voyer et al., ${ }^{47}$ is available as an electronic supplement to that paper, as well as for download at the EarthChem Library. ${ }^{59}$

For hot spots, we rely heavily on an extensive new data set for Hawaiian melt inclusions reported by Marske and Hauri ${ }^{60}$ consisting of major, trace, and volatile element data on 915 olivine-hosted melt inclusions in 29 samples of submarine-erupted pillow lavas and subaerial tephra deposits from the shield-building stage of five Hawaiian volcanoes (Figure 9.4). Tucker et al. ${ }^{61}$ estimated bulk (dissolved + bubble) $\mathrm{CO}_{2}$ contents in 437 of the Hawaiian melt inclusions studied by Marske and Hauri. ${ }^{60}$ These data are supplemented by melt inclusion data from other hot spot localities where shrinkage of bubble dimensions are reported, namely the Azores, ${ }^{62}$ Canaries, ${ }^{63}$ and Iceland. ${ }^{64,65}$ The compiled OIB melt inclusion dataset may be downloaded from the EarthChem Library. ${ }^{66}$ We emphasize, however, that none of the microbeam and statistical methods applied to melt inclusions can account for $\mathrm{CO}_{2}$ lost from magmas prior to melt inclusion entrapment in their crystal hosts. 
(b)
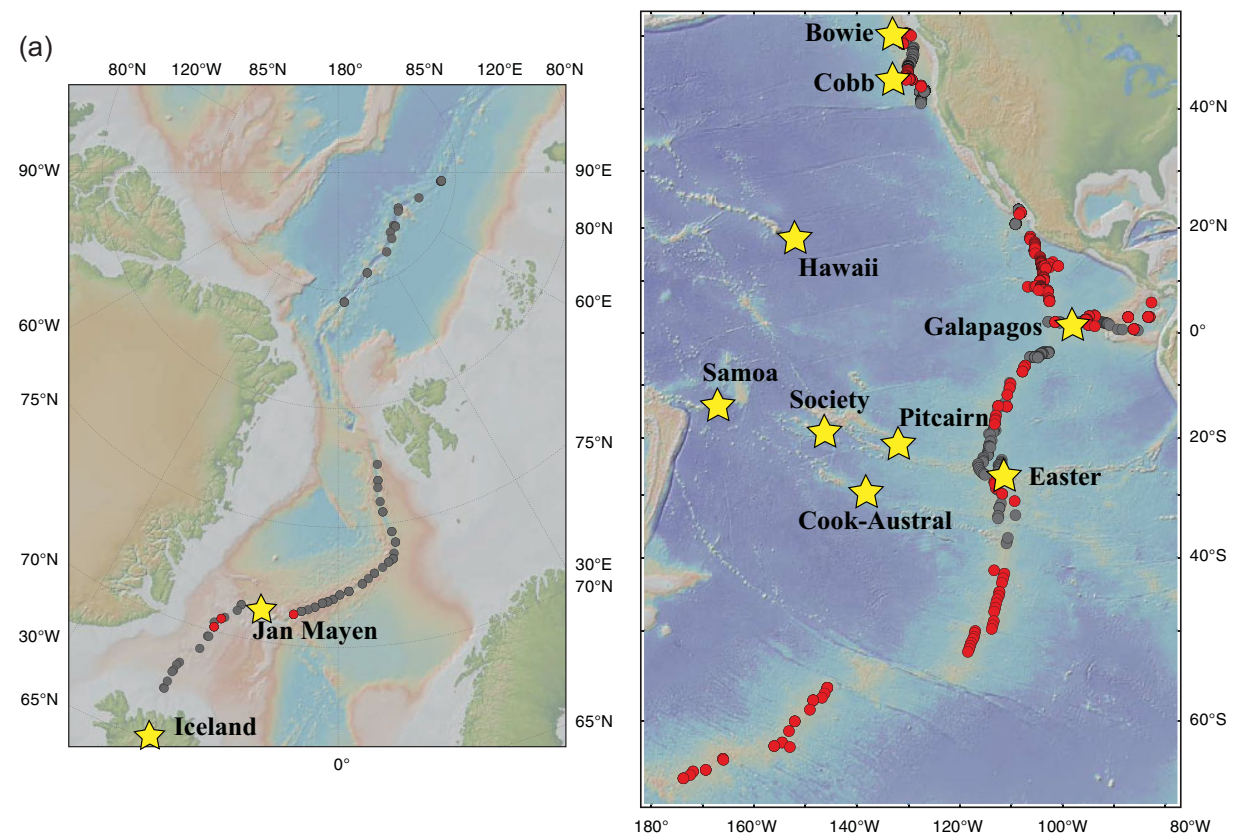

(c)

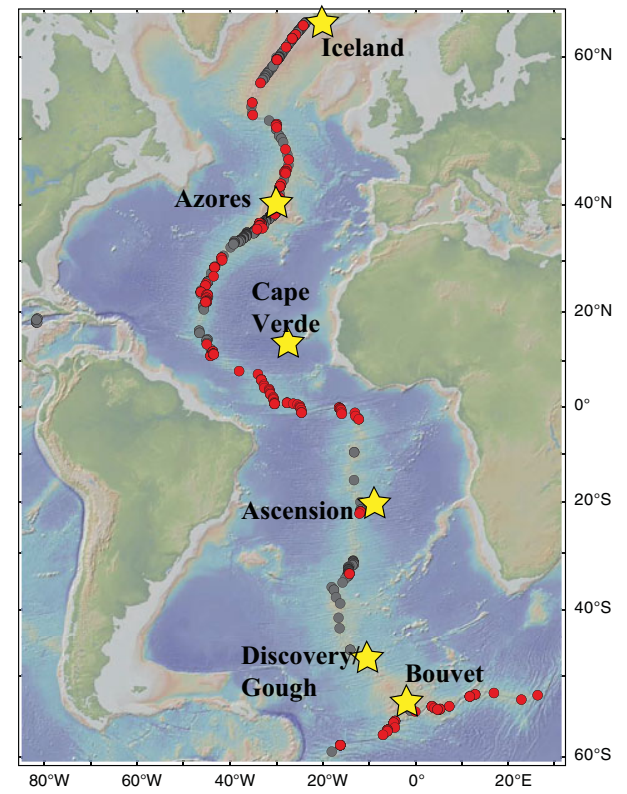

(d)

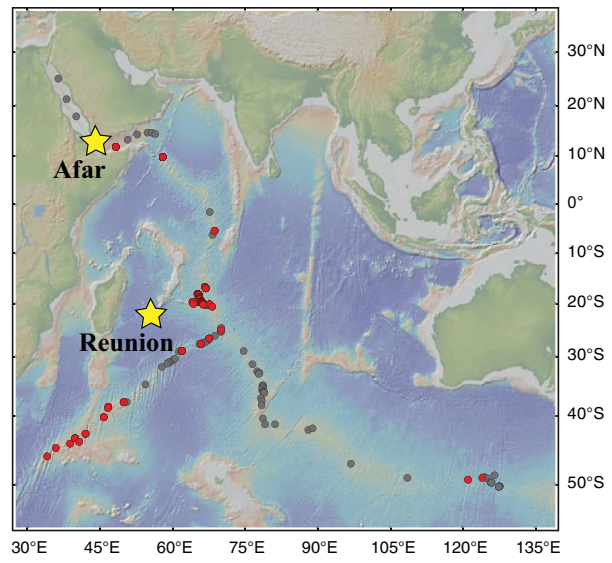

Figure 9.2 GeoMapApp figures showing MORB sample locations from the study of Le Voyer et $\mathrm{al}^{47}$ (red circles) and locations of previously published MORB samples (gray circles). Hot spots with estimated $\mathrm{CO}_{2}$ fluxes are shown as yellow stars. (a) Arctic Ocean basin; (b) Pacific Ocean basin; (c) Atlantic Ocean basin; (d) Indian Ocean basin. 
(a)

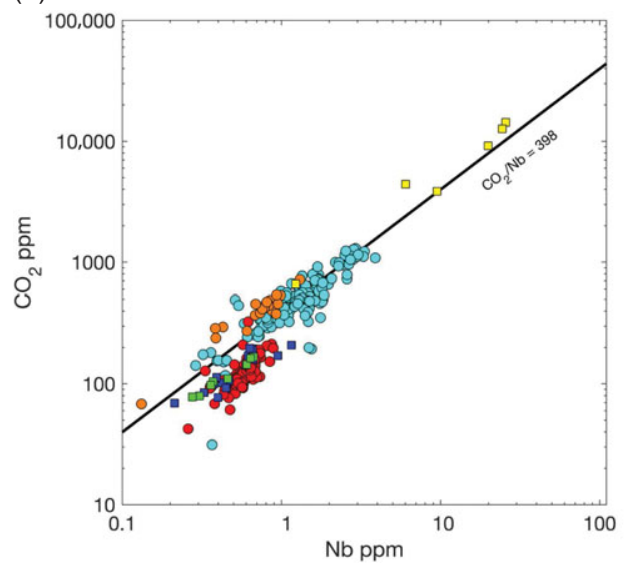

(b)

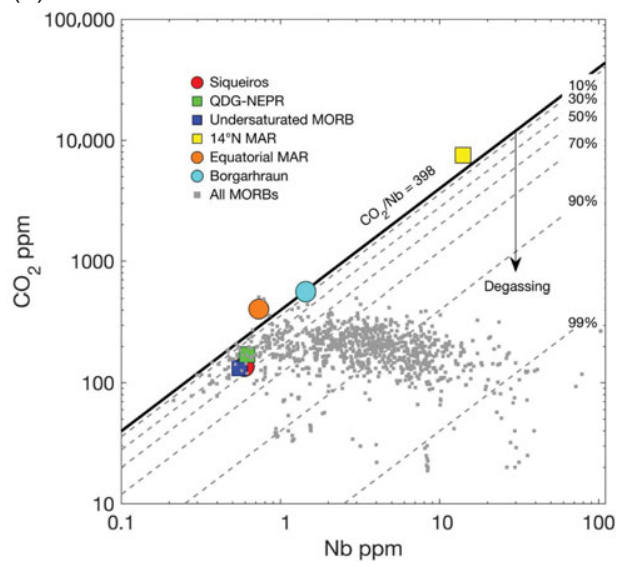

Figure $9.3 \mathrm{CO}_{2}-\mathrm{Nb}$ data for (a) vapor-undersaturated sample suites of submarine glasses and melt inclusions and (b) individual MORBs, with undersaturated sample suites from (a) represented by average compositions (boxes). The $\mathrm{CO}_{2} / \mathrm{Nb}=398$ line represents the average of the individual average $\mathrm{CO}_{2} / \mathrm{Nb}$ ratio for each of the undersaturated samples suites. For any given sample, one can gain a sense of the extent of $\mathrm{CO}_{2}$ degassing by comparing the sample's $\mathrm{CO}_{2} / \mathrm{Nb}$ ratio to the average $\mathrm{CO}_{2} / \mathrm{Nb}$ ratio of undegassed samples.

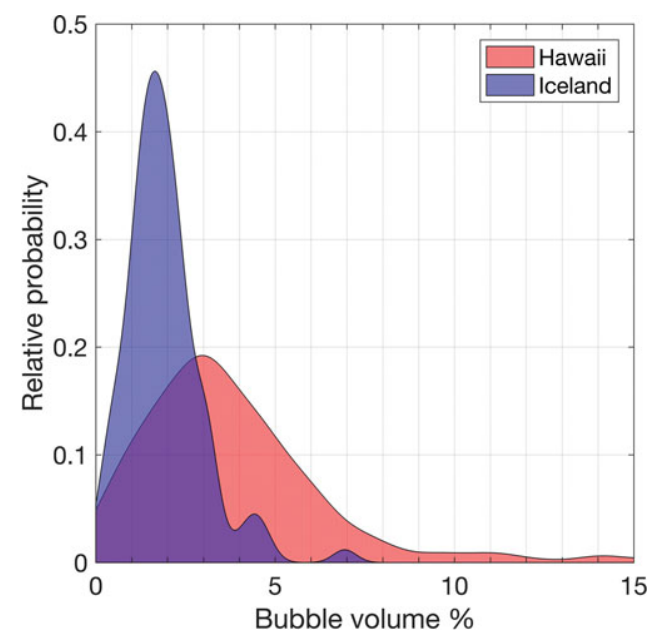

Figure 9.4 Probability distribution of the ratio of vapor bubble volume to total melt inclusion volume for vapor bubbles in melt inclusions from Hawaii ${ }^{61}$ and Iceland. ${ }^{64,65}$ Bubbles in Iceland melt inclusions strongly peak near 1.5 vol.\%, whereas bubbles in Hawaiian melt inclusions are more variable and peak around 3 vol.\%.

\subsection{Fluxes of $\mathrm{CO}_{2}$ from the Global Mid-Ocean Ridge System}

The samples compiled by Le Voyer et al. ${ }^{47}$ were assigned to individual ridge segments based on a comparison of their sampling coordinates with the global spreading center 
segment catalog of Gale et al. ${ }^{36}$ (Figure 9.2). Segment-average volatile concentrations were calculated for all segments that contained an on-axis sample analyzed for $\mathrm{H}_{2} \mathrm{O}, \mathrm{CO}_{2}, \mathrm{~F}, \mathrm{~S}$, and/or $\mathrm{Cl}$. Segment averages for the volatile data were corrected to $\mathrm{MgO}=8 \mathrm{wt} . \%$ and to compositions in equilibrium with $\mathrm{Fo}_{90}$ olivine in order to compare with the fractionationnormalized database of Gale et al. ${ }^{17}$ We note that correction for crystal fractionation cannot account for the irreversible loss of $\mathrm{CO}_{2}$ by degassing, although we estimate primary magma $\mathrm{CO}_{2}$ contents using $\mathrm{Ba}$ and $\mathrm{Rb}$ as proxies, as explained below.

MORBs are erupted under hydrostatic pressure on the seafloor, determined by the water depth at the site of MORB collection. The solubility of $\mathrm{CO}_{2}$ in MORBs is strongly dependent on pressure, ${ }^{37,41}$ and so dissolved $\mathrm{CO}_{2}$ concentrations in MORBs correlate with the pressure of eruption on the seafloor. ${ }^{67}$ However, many MORBs have dissolved $\mathrm{CO}_{2}$ contents in excess of the equilibrium solubility of $\mathrm{CO}_{2}$ predicted at the eruption pressure. This oversaturation is due to rapid melt ascent during eruption, during which diffusion of carbon in the melt is too slow to maintain equilibrium between the dissolved $\mathrm{CO}_{3}{ }^{2-}$ in the melt and the $\mathrm{CO}_{2}$ vapor within the vesicles (Figure 9.1b). ${ }^{37,38,67-69}$

The $\mathrm{CO}_{2}-\mathrm{H}_{2} \mathrm{O}$ solubility model of Dixon et al. ${ }^{39}$ has typically been used to constrain vapor saturation pressure $\left(\mathrm{P}_{\text {sat }}\right)$ in MORBs because they determined $\mathrm{CO}_{2}$ and $\mathrm{H}_{2} \mathrm{O}$ solubility specifically on MORB melt compositions. When we use measured $\mathrm{CO}_{2}$ and $\mathrm{H}_{2} \mathrm{O}$ contents in MORBs to calculate $\mathrm{P}_{\text {sat }}$ using the Dixon et al. ${ }^{39}$ model and compare these with the pressures of MORB sample collection $\left(\mathrm{P}_{\text {sample }}\right)$, a subset of the data scatter around the 1:1 line (line in Figure 9.5) where vapor saturation pressures are close to those corresponding to the sampling location. A large number of samples are also demonstrably oversaturated in a $\mathrm{CO}_{2}-\mathrm{H}_{2} \mathrm{O}$ vapor and thus plot to high values of $\mathrm{P}_{\text {sat }}$ (above line in Figure 9.5), in good agreement with the presence of vapor bubbles in almost all MORB samples. ${ }^{69}$

Two other solubility models are often used as alternatives to the Dixon et al. ${ }^{39}$ model: Papale et al. ${ }^{70}$ and Ghiorso and Gualda. ${ }^{71}$ The model of Papale et al. ${ }^{70}$ (green field in Figure 9.5) produces $\mathrm{P}_{\text {sat }}$ values that are $60 \%$ lower on average compared with Dixon et al., ${ }^{39}$ which suggests that most MORBs are vapor undersaturated. Vesicle abundances observed in MORBs, however, contradict this prediction ${ }^{69}$ because samples that are vapor undersaturated should not have vesicles. ${ }^{49,50,52}$ The Papale et al. ${ }^{70}$ model thus likely underestimates vapor saturation pressures in MORBs. The Papale et al. ${ }^{70}$ model was calibrated over a very wide range in melt compositions, whereas the Dixon et al. ${ }^{39}$ model was calibrated specifically on MORB compositions, so disagreement between these models is perhaps not surprising. More recently, the $\mathrm{CO}_{2}-\mathrm{H}_{2} \mathrm{O}$ solubility model of Ghiorso and Gualda ${ }^{71}$ (pink field in Figure 9.5) results in $\mathrm{P}_{\text {sat }}$ values that are $20 \%$ lower on average compared with Dixon et al., ${ }^{39}$ producing good agreement with $\mathrm{P}_{\text {sample }}$ values. The Ghiorso and Gualda ${ }^{71}$ model thus also predicts more samples than Dixon et al. ${ }^{39}$ to be vapor undersaturated. Both models provide reasonable estimates of vapor saturation pressures, but we prefer the model of Dixon et al. ${ }^{39}$ because it is calibrated specifically for MORBs and it predicts that fewer MORBs are vapor undersaturated, which is consistent with the presence of vesicles in the vast majority of MORBs. 


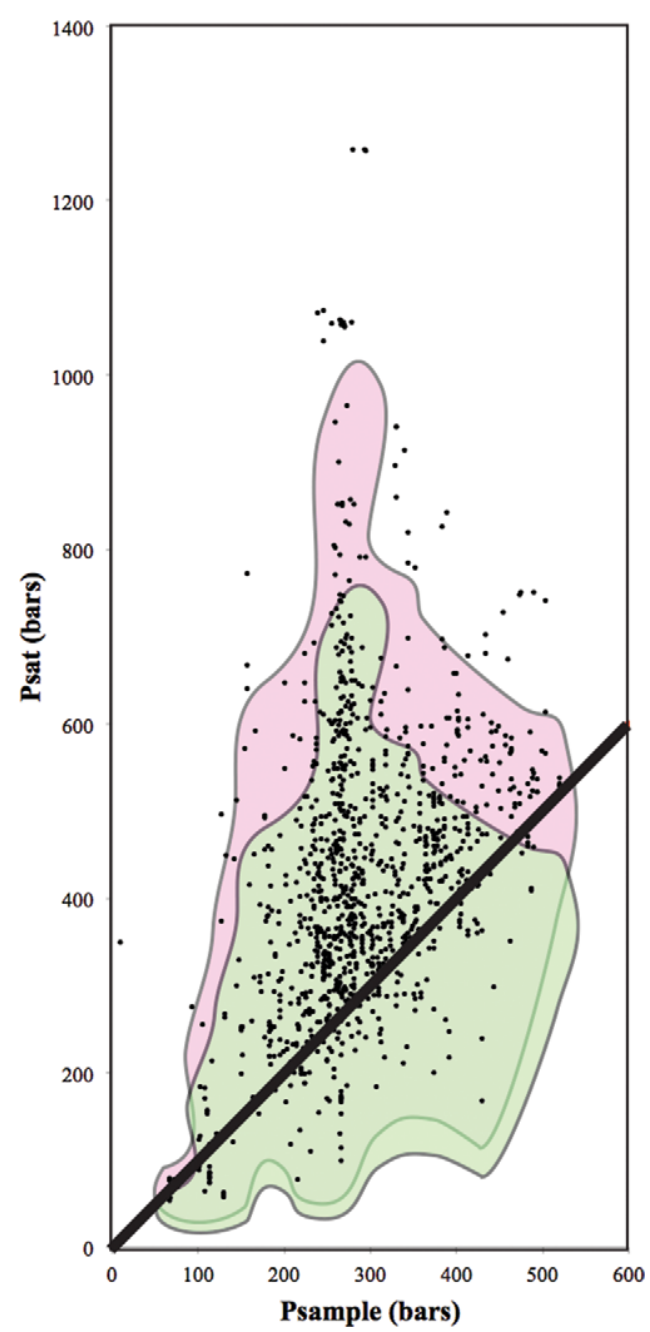

Figure 9.5 Pressure of MORB sample collection on the seafloor $\left(\mathrm{P}_{\text {sample }}\right)$ versus pressure of vapor saturation $\left(\mathrm{P}_{\text {sat }}\right)$ calculated from the $\mathrm{CO}_{2}$ and $\mathrm{H}_{2} \mathrm{O}$ contents of MORB samples using the vapor solubility model of Dixon et al. ${ }^{39}$ The $1: 1$ line $\left(\mathrm{P}_{\text {sat }}=\mathrm{P}_{\text {sample }}\right)$ corresponds to equilibrium of $\mathrm{CO}_{2}-$ $\mathrm{H}_{2} \mathrm{O}$ contents at seafloor pressures. The pink field encloses the $\mathrm{P}_{\text {sat }}$ values calculated from the solubility model of Ghiorso and Gualda, ${ }^{71}$ which produces $\mathrm{P}_{\text {sat }}$ estimates $20 \%$ lower than those of Dixon et al. ${ }^{39}$ the green field encloses the $\mathrm{P}_{\text {sat }}$ values calculated from the solubility model of Papale et al., ${ }^{70}$ which are $60 \%$ lower than those of Dixon et al. ${ }^{39}$

\subsubsection{MORB Melt Inclusions and the Usefulness of Volatile/Nonvolatile Element Ratios}

Because $\mathrm{CO}_{2}$ has degassed irreversibly from most MORBs, the flux of $\mathrm{CO}_{2}$ from the MORB mantle is often determined by establishing the mantle ratio of $\mathrm{CO}_{2}$ to another 
element whose flux is well constrained. An element often used this way is helium, as the upper mantle ${ }^{3} \mathrm{He}$ flux is determined from oceanographic measurements ${ }^{72-74}$ or measurements in MORBs. ${ }^{75} \mathrm{CO}_{2} /{ }^{3} \mathrm{He}$ ratios measured in MORBs must be corrected for fractionation during magmatic degassing, and an equilibrium degassing model is often used for this purpose. ${ }^{10,76,77}$ However, Tucker et al. ${ }^{75}$ showed that MORB degassing is influenced by kinetic effects not accounted for in equilibrium degassing models. Using a disequilibrium degassing model, Tucker et al. ${ }^{75}$ estimated a mantle $\mathrm{CO}_{2}$ flux of $59 \mathrm{Tg} / \mathrm{yr}$, although the extent of $\mathrm{CO}_{2}$ fractionation from other volatile elements during degassing and the total mantle $\mathrm{CO}_{2}$ flux strongly depend on poorly constrained diffusivities of carbon in basaltic melt.

To avoid reliance on degassing models and uncertainties in their critical parameters, we seek undegassed samples to develop nonvolatile proxies for the $\mathrm{CO}_{2}$ contents of primary mantle melts (melts in equilibrium with mantle olivine of $\mathrm{Fo}_{90}$ ). We therefore turn to melt inclusions. By virtue of being encapsulated in rigid host minerals, melt inclusions gain additional protection from degassing, and their volatile concentrations are not constrained by eruption depth as described in the preceding section. Indeed, some suites of melt inclusions lack vapor bubbles and are well established as being vapor (and hence carbon) undersaturated. For a proxy, we turn to highly incompatible nonvolatile trace elements with similar behavior to carbon during partial melting of the mantle (Figure 9.1). Analyses of rare undegassed melt inclusions, ${ }^{49,52,53}$ rare undegassed MORBs,${ }^{50,51}$ and experimental studies $^{78}$ establish that the nonvolatile elements $\mathrm{Rb}, \mathrm{Ba}, \mathrm{Nb}$, and $\mathrm{Th}$ behave similarly to $\mathrm{CO}_{2}$ during mantle melting. In undegassed samples, $\mathrm{CO}_{2}$ concentrations correlate with $\mathrm{Rb}$, $\mathrm{Ba}, \mathrm{Nb}$, and Th. Moreover, the $\mathrm{CO}_{2} / \mathrm{Ba}$ and $\mathrm{CO}_{2} / \mathrm{Rb}$ ratios of undegassed mantle-derived melts are approximately constant. ${ }^{53}$ Two fundamental assumptions follow from these observations and underpin this contribution: (1) mantle processes do not fractionate carbon from $\mathrm{Ba}$ and $\mathrm{Rb}$; and (2) MORB $\mathrm{Ba}$ and $\mathrm{Rb}$ concentrations can be used as proxies for $\mathrm{CO}_{2}$ in partially degassed MORBs and OIBs. Furthermore, we suggest that loss of $\mathrm{CO}_{2}$ by degassing can be detected by the presence (or lack thereof) of a correlation of $\mathrm{CO}_{2}$ with incompatible trace elements.

The first such correlation was observed for MORB melt inclusions from the Siqueiros Fracture Zone on the East Pacific Rise, where depleted MORB (D-MORB) is erupted at great water depth, inhibiting $\mathrm{CO}_{2}$ loss even from the erupted magmas. ${ }^{49}$ Subsequent studies of MORB melt inclusions, from less-depleted ridge segments and containing shrinkage bubbles, generally observed degassed magmas with no correlations of $\mathrm{CO}_{2}$ with other trace elements. ${ }^{54,55}$ Recently, two other suites of melt inclusions, showing $\mathrm{CO}_{2}$ correlating with $\mathrm{Rb}, \mathrm{Ba}, \mathrm{Nb}, \mathrm{Th}$, and other trace elements, have been reported from the Mid-Atlantic Ridge ${ }^{52}$ and northern Iceland. ${ }^{53}$ These recently reported melt inclusion suites were free of vapor bubbles within the melt inclusions, with the exception of the most enriched of the Iceland melt inclusions, for which bubble measurements were made to account for the influence of their $\mathrm{CO}_{2}$ budget on the overall $\mathrm{CO}_{2}$ content of the inclusions. ${ }^{53}$ Additionally, Michael and Graham ${ }^{50}$ and Shimizu et al. ${ }^{51}$ identified limited suites of deeply erupted D-MORB glasses that also show correlations of $\mathrm{CO}_{2}$ with incompatible 
trace elements. Hauri et al. ${ }^{53}$ showed that vapor-undersaturated MORBs have average $\mathrm{CO}_{2} / \mathrm{Rb}(991 \pm 26 \%)$ and $\mathrm{CO}_{2} / \mathrm{Ba}(81.3 \pm 56 \%)$ ratios that are more uniform than $\mathrm{CO}_{2} / \mathrm{Nb}$ or $\mathrm{CO}_{2} /$ Th ratios. The ratio of the measured $\mathrm{CO}_{2} / \mathrm{Ba}$ ratio to the average $\mathrm{CO}_{2} / \mathrm{Ba}$ ratio for undegassed MORBs indicates that a majority of MORB samples have degassed $>80 \%$ of their initial $\mathrm{CO}_{2}$ (Figure 9.3).

Although vapor-undersaturated MORBs with relatively uniform $\mathrm{CO}_{2} / \mathrm{Ba}, \mathrm{CO}_{2} / \mathrm{Rb}$, $\mathrm{CO}_{2} / \mathrm{Th}$, and $\mathrm{CO}_{2} / \mathrm{Nb}$ ratios have mostly been interpreted to be undegassed, alternative interpretations have been explored that bear on how accurately these ratios record those in the mantle sources of MORB. Rosenthal et al., ${ }^{78}$ argued that scattering in observed $\mathrm{CO}_{2} / \mathrm{Ba}$ and $\mathrm{CO}_{2} / \mathrm{Nb}$ ratios in vapor-undersaturated MORBs could be due to undetected degassing of $\mathrm{CO}_{2}$ in amounts small enough to preserve $\mathrm{CO}_{2}-\mathrm{Ba}-\mathrm{Nb}$ correlations. Matthews et al. ${ }^{79}$ modeled this undetected degassing as a partial degassing and mixing process, where nearfractional melts of the mantle are partially degassed at a specified depth and partially mixed. Despite being partially degassed, modeled melt mixtures were shown to retain positive correlations between $\mathrm{CO}_{2}$ and nonvolatile trace elements while delineating average $\mathrm{CO}_{2}$ /nonvolatile trace element ratios that underestimated those of the mantle source. A defining characteristic of the model results from Matthews et al. ${ }^{79}$ is the prediction that sample suites that partially degas will show a gradual as opposed to a sharp transition from positive to negative Pearson correlation coefficients between $\mathrm{CO}_{2} / \mathrm{El}$ and $1 / \mathrm{El}$ ratios (where $\mathrm{El}$ is a nonvolatile trace element) with increasing compatibility of the El. Applying their model results to natural melt inclusion populations, Matthews et al. ${ }^{79}$ argued that Pearson correlation coefficients in the equatorial Mid-Atlantic Ridge melt inclusions reported by Le Voyer et al. ${ }^{52}$ show a gradual transition from positive to negative correlation coefficients, and that the melt inclusions were partially degassed. They also argued that other MORB data sets are consistent with partial degassing, and that rather than the average $\mathrm{CO}_{2} / \mathrm{Ba}$ ratio in $\mathrm{CO}_{2}$-undersaturated MORBs, the maximum $\mathrm{CO}_{2} / \mathrm{Ba}$ ratio of $\sim 140$ provides a more reliable estimate of the $\mathrm{CO}_{2} / \mathrm{Ba}$ ratio of the mantle source.

The study of Shimizu et al. ${ }^{80}$ evaluated whether the partial degassing and mixing process described by Matthews et al. ${ }^{79}$ can reproduce the data for the olivine-hosted MORB melt inclusions from the Garrett and Siqueiros transform faults on the East Pacific Rise and found that it is difficult to fully explain their Pearson correlation coefficients between the $\mathrm{CO}_{2} / \mathrm{El}$ and 1/El ratios (Figure 9.6). To explain the observed coefficients, Shimizu et al. ${ }^{80}$ considered the effect of analytical uncertainties in the model by adding noise to the modeled concentrations of $\mathrm{CO}_{2}$ and $\mathrm{EI}$, simulating the analytical uncertainties during measurements of the Siqueiros and Garrett melt inclusions. They demonstrated that when analytical uncertainties are considered, the correlations between the $\mathrm{CO}_{2} / \mathrm{El}$ and 1/El ratios of an undegassed model show a gradual transition from positive to negative similar to a partially degassed model (Figure 9.6). They argued that although partial degassing cannot be ruled out, it may not be required to explain the Pearson correlation coefficients in the Siqueiros and Garrett melt inclusions (Figure 9.6).

Isotopic heterogeneity within melt inclusion populations derived from individual samples has been reported by several studies, ${ }^{81-84}$ which can be explained only if the melt 


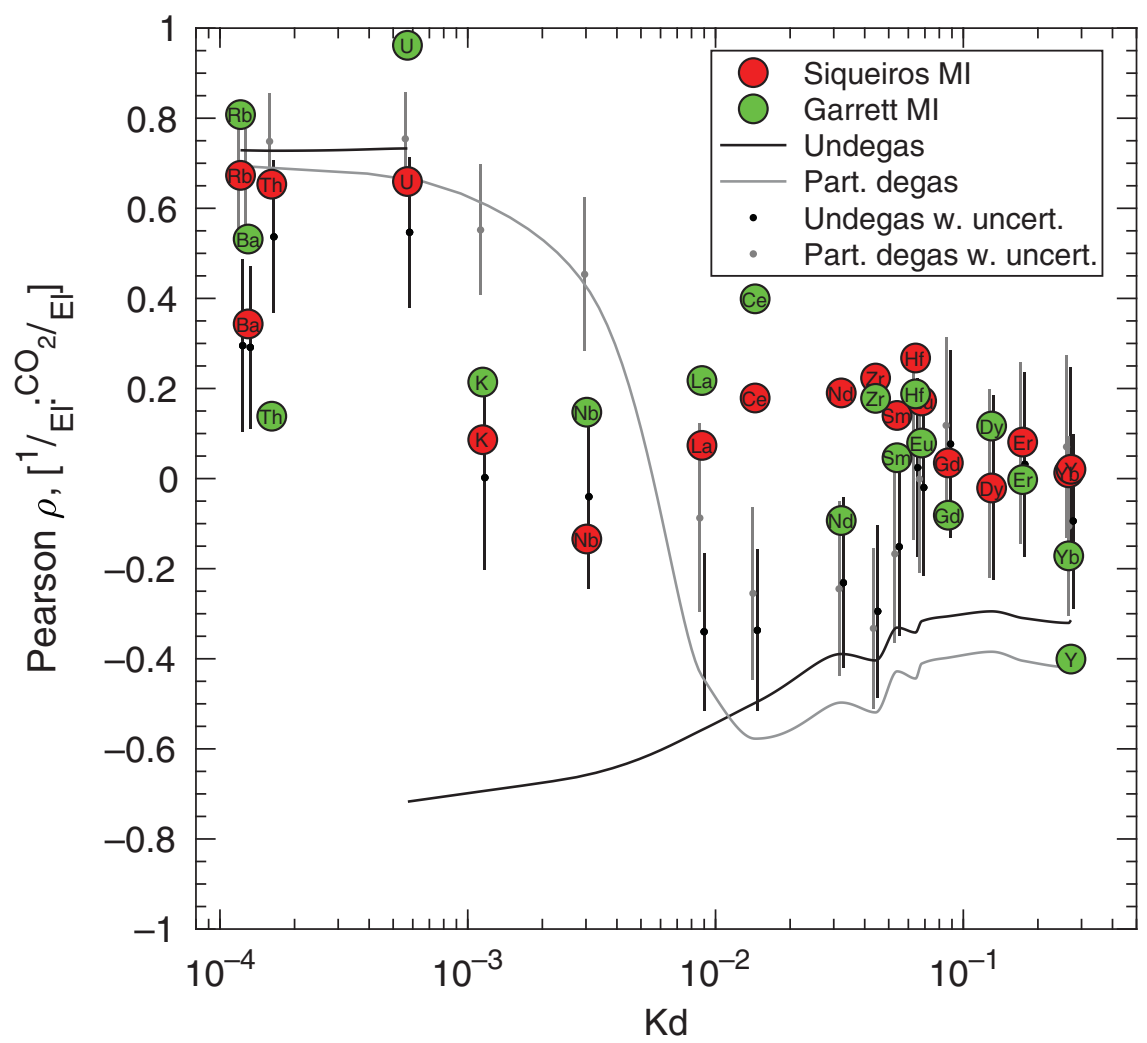

Figure 9.6 Pearson correlation coefficients for 1/El versus $\mathrm{CO}_{2} / \mathrm{El}$ (where $\mathrm{El}$ is an incompatible trace element) for Siqueiros and Garrett melt inclusions (MIs) plotted against the bulk partition coefficients of the EI. ${ }^{80}$ Garrett MIs have been filtered for anomalously depleted MIs with high analytical uncertainties. Bulk partition coefficients are from Rosenthal et al. ${ }^{78}$ for $\mathrm{C}$ and Kelemen et al. ${ }^{173}$ for nonvolatile trace elements. Solid gray and black lines show correlation coefficients generated by the model of Matthews et al. ${ }^{79}$ conducted using the pHMELTS model ${ }^{174-176}$ to generate near-fractional melts of the DDMM from Workman and Hart, ${ }^{177}$ which were then mixed using the model of Rudge et al. ${ }^{178}$ The black and gray lines are the undegassed and partially degassed models, respectively, both of which do not include the analytical uncertainties. The black and gray dots are mean and $2 \sigma$ uncertainties of Pearson correlation coefficients generated by the undegassed and partially degassed models ran 1000 times, both of which include analytical uncertainties ranging from $6 \%$ to $32 \%(2 \sigma)$ depending on the element. In the partial degassing model, partial degassing is done using the $\mathrm{CO}_{2}$ solubility model of Shishkina et al. ${ }^{179}$ at $7 \mathrm{~km}$ in the oceanic crust underneath $4 \mathrm{~km}$ of seawater.

inclusion suite represents mixtures of melts from a heterogeneous source. Indeed, chemical and isotopic heterogeneity has been observed in MORBs by numerous studies, suggesting generation through melting of a heterogeneous mantle source ${ }^{25,35,85-87}$ (and see expanded discussion in Section 9.3.2). This heterogeneity typically takes the form of mixing between melts from depleted and enriched sources with low and high concentrations of trace elements, respectively. In this mixing scenario, trace element ratios like $\mathrm{CO}_{2} / \mathrm{Ba}$ and 
$\mathrm{CO}_{2} / \mathrm{Nb}$ are dominated by melts from the more enriched component with higher trace element abundances, while melts from the depleted source act to dilute the signature of melts from the enriched source. As a result, the population average of a ratio of two highly incompatible elements (such as $\mathrm{CO}_{2} / \mathrm{Ba}$ ) might also be modified by mixing of melts from heterogeneous sources, having an important and unexplored effect on the modeling results of Matthews et al. ${ }^{79}$ While it is beyond the scope of this chapter to provide detailed discussion of all of the processes that lead to compositional heterogeneity at ridges and hot spots, we note that the Pearson correlation coefficients between the $\mathrm{CO}_{2} / \mathrm{El}$ and $1 / \mathrm{El}$ ratios for each of the vapor-undersaturated sample suites is not completely explained by either partial degassing and mixing or melting of a single mantle source (e.g. La, Ce, $\mathrm{Nd}$, and $\mathrm{Hf}$ in Figure 9.6). Given this and the result that gradual changes in Pearson correlation coefficients between $\mathrm{CO}_{2} / \mathrm{El}$ and $1 / \mathrm{El}$ ratios from positive to negative may not require partial degassing (Figure 9.6), we postulate that average $\mathrm{CO}_{2} / \mathrm{El}$ ratios observed in vaporundersaturated melt inclusions reflect those of the mantle source(s) involved in melting, and that these ratios apply to the entire global ridge system.

\subsubsection{Variations in Primary $\mathrm{MORB} \mathrm{CO}_{2}$ Contents and $\mathrm{CO}_{2}$ Fluxes}

We describe here the central methodology of this contribution. Trace elements vary among MORB segments by a factor of 20 , and this cannot be explained by variations in the extent of melting, ${ }^{17,20,21}$ but instead requires mantle heterogeneity. At the segment, ${ }^{34}$ basin, ${ }^{35}$ and global scales, ${ }^{36}$ trace element ratios correlate with some, but not all, radiogenic isotopes. For example, segment average $\mathrm{Ba} / \mathrm{Nb}$ ratios correlate with ${ }^{87} \mathrm{Sr} /{ }^{86} \mathrm{Sr}^{36}$ While correlations between trace elements and isotopes can be complex because isotopes represent timeintegrated histories and trace elements are highly sensitive to recent fractionation events, trace elements are highly correlated among themselves. Carbon - another trace element has been shown to correlate with the highly incompatible trace elements and varies on an order that exceeds that which can be produced by ridge processes. By analogy with trace elements, we consequently infer large variations in primary mantle $\mathrm{CO}_{2}$ concentrations due to mantle heterogeneity, which we calculate on the segment scale below.

The restricted ranges in $\mathrm{CO}_{2} / \mathrm{Ba}$ and $\mathrm{CO}_{2} / \mathrm{Rb}$ in undegassed MORBs permit an estimation of the initial primary $\mathrm{CO}_{2}$ concentrations of MORB magmas, given an estimate of their primary trace element abundances. Gale et al. ${ }^{17,36}$ provide such estimates based on the compositions of MORB magmas averaged by ridge segment, and corrected for shallowlevel crystal fractionation to $\mathrm{MgO}=8 \mathrm{wt}$. $\%$ and also further corrected to be in equilibrium with $\mathrm{FO}_{90}$ olivine. Le Voyer et al. ${ }^{47}$ estimated primary MORB magma $\mathrm{CO}_{2}$ for 387 segments that contain data for $\mathrm{Ba}$ and/or $\mathrm{Rb}$ out of the $711 \mathrm{MORB}$ spreading ridge segments identified by Gale et al. ${ }^{36}$ These segment-average concentrations were then multiplied by the undegassed-average ratios from Hauri et al. ${ }^{53}$ of $\mathrm{CO}_{2} / \mathrm{Rb}(991)$ and $\mathrm{CO}_{2} / \mathrm{Ba}(81.3)$ to calculate segment-averaged primary $\mathrm{CO}_{2}$ concentrations. Unsurprisingly, the segment-average primary $\mathrm{CO}_{2}$ contents (as derived from $\mathrm{Ba}$ and $\mathrm{Rb}$ ) correlate well with segment-averaged primary Th and $\mathrm{K}_{2} \mathrm{O}$ (Figure 9.7). These $\mathrm{CO}_{2}$ abundances range widely, from a low of $104 \mathrm{ppm} \mathrm{CO}_{2}$ at a 

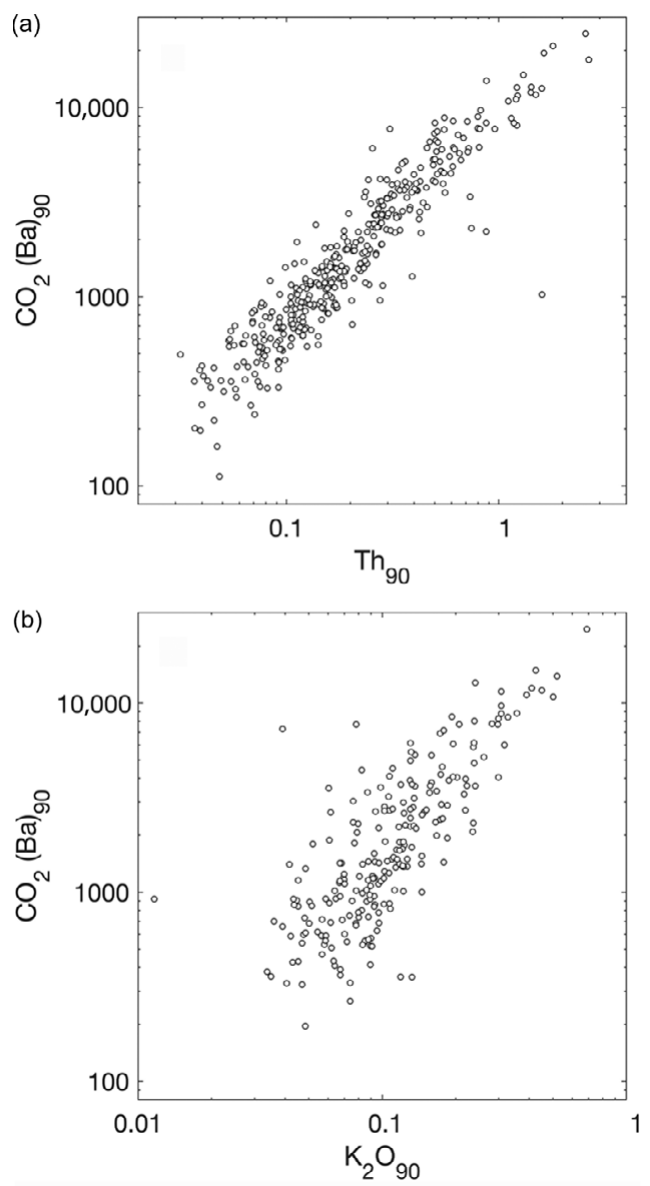

Figure 9.7 Segment-averaged primary MORB compositions corrected for low-pressure fractionation to equilibrium with $\mathrm{Fo}_{90}$ olivine. $\mathrm{CO}_{2}(\mathrm{Ba})_{90}$ versus (a) $\mathrm{Th}_{90}$ and (b) $\mathrm{K}_{2} \mathrm{O}_{90}$ from the study of Le Voyer et al., ${ }^{47}$ who estimated primary magma $\mathrm{CO}_{2}$ contents from the average $\mathrm{MORB} \mathrm{CO}_{2} / \mathrm{Ba}$ ratio (81.3) and segment-average $\mathrm{Ba}_{90}$ concentrations.

depleted segment in the Galapagos Spreading Center to a high of $1.90 \mathrm{wt} . \% \mathrm{CO}_{2}$ at a highly enriched segment of the Juan de Fuca Ridge. The distribution of primary melt $\mathrm{CO}_{2}$ contents is strongly skewed with a near log-normal distribution. The median $\mathrm{CO}_{2}$ content is $1107 \mathrm{ppm}$ and the mean is $2139 \mathrm{ppm}$. To determine the mode ("most likely" $\mathrm{CO}_{2}$ content), we applied a kernel density analysis with an optimal bandwidth of 318 (Bowman \& Azzalini, 1997 ${ }^{182}$ ), and obtained $621 \mathrm{ppm}$. This preferred value for "typical primary MORB" $\left(621 \mathrm{ppm} \mathrm{CO}_{2}\right)$ is similar to the analytical mode (486 ppm), which assumes a true log-normal distribution. (Note that the original printing of Le Voyer et al. (2019) ${ }^{59}$ incorrectly referred to $2100 \mathrm{ppm}$ as median primary $\mathrm{CO}_{2}$. This contribution revises that error.) 
Nearly five decades of deep-water oceanographic research, coupled with ocean drilling by the Deep Sea Drilling Program (DSDP) and the International Ocean Drilling Program (IODP), have demonstrated a limited range of crustal thickness of $6 \pm 1 \mathrm{~km},{ }^{20,88,89}$ and at variable spreading rates that are well determined globally. ${ }^{90}$ Given the relationship between crustal thickness and seafloor depth, ${ }^{20,88,91}$ magma production rates at mid-ocean ridges are readily calculated from the product of ridge length, crustal thickness, and spreading rate. ${ }^{11}$ Behn and Grove $^{88}$ and Van Avendonk et al. ${ }^{92}$ summarized seismically determined measurements of crustal thickness at ridge axes, which varies from $2 \mathrm{~km}$ at the slow-spreading Gakkel Ridge to $30 \mathrm{~km}$ at central Iceland and is a product of the local magma production rate and spreading rate. The crustal thickness of ridge segments correlates with ridge depth (reflecting isostatic compensation of MORB crust at the ridge axis). With this, Le Voyer et al. ${ }^{47}$ estimated the crustal thickness at all of the 711 MORB segments defined by Gale et al. ${ }^{36}$ based on the axial depth. Le Voyer et al. ${ }^{47}$ then determined a segment-average magma production rate by multiplying the crustal thickness by the segment spreading rate, which was then used to calculate the fluxes of $\mathrm{CO}_{2}$ (and other elements) on a segment-by-segment basis.

$\mathrm{CO}_{2}$ fluxes, normalized by ridge length, vary by a factor of $>100$ because they are the product of local primary magma $\mathrm{CO}_{2}$ content and local magma production rate, which are uncorrelated. Fluxes of $\mathrm{CO}_{2}$ vary from $1.52 \times 10^{6}$ to $4.74 \times 10^{8} \mathrm{~mol} / \mathrm{yr} / \mathrm{km}$. High $\mathrm{CO}_{2}$ fluxes are typically correlated with high primary $\mathrm{CO}_{2}$ in the magma (Figure 9.8), reinforcing the observations made above that variations in the MORB primary magma $\mathrm{CO}_{2}$ content are mostly driven by variations in mantle composition rather than magma production dynamics or mantle temperature. ${ }^{47}$

Integrated over the length of the global mid-ocean ridge system, the global MORB magma production rate is $16.5 \mathrm{~km}^{3} / \mathrm{yr}$ (lower than the estimate of $21 \mathrm{~km}^{3} / \mathrm{yr}$ from Crisp ${ }^{11}$ ), and the total flux of $\mathrm{CO}_{2}$ is $1.32 \times 10^{12} \mathrm{~mol} / \mathrm{yr}{ }^{47}$ This estimate is significantly higher than that of Saal et al., ${ }^{49}$ which is based on depleted Siqueiros Fracture Zone melt inclusions. Our estimate is lower than the estimate of Cartigny et al., ${ }^{48}$ which is based on enriched MORBs from $14^{\circ} \mathrm{N}$ and $34^{\circ} \mathrm{N}$ on the Mid-Atlantic Ridge. Marty and Tolstikhin, ${ }^{10}$ Michael and Graham, ${ }^{50}$ and Hauri et al. ${ }^{53}$ give $\mathrm{CO}_{2}$ fluxes that are nearly a factor of two higher than the integrated value summed over the detailed fluxes determined on a segment-by-segment basis by Le Voyer et al. ${ }^{47}$

The MORB flux of $\mathrm{CO}_{2}$ degassed at the ridge axis is ultimately dissolved into the overlying water column, either instantly by eruptive degassing ( $~ 80 \%)$ or later stripped out by hydrothermal circulation, where it becomes part of the marine bicarbonate cycle. Short-term global effects of large variations in the ridge $\mathrm{CO}_{2}$ flux are thus muted by the $\sim 100,000$ year residence time of carbon dissolved in seawater, ${ }^{93}$ and thus variations in the ridge $\mathrm{CO}_{2}$ flux are unlikely to influence short-term surface climate conditions while the ridge is submerged. Only when the mid-ocean ridge system is exposed above sea level, such as at Iceland today, will there be a significant delivery of $\mathrm{CO}_{2}$ from the mid-ocean ridge mantle directly into the atmosphere. On longer timescales, the ridge $\mathrm{CO}_{2}$ flux is dwarfed by the deposition of carbonate sediments and organic carbon on the seafloor and of carbonate alteration veins within the crustal and mantle sections of the oceanic lithosphere, which make the seafloor a net sink for carbon by a large factor compared with its initial magmatic budget. ${ }^{8,94-96}$ 

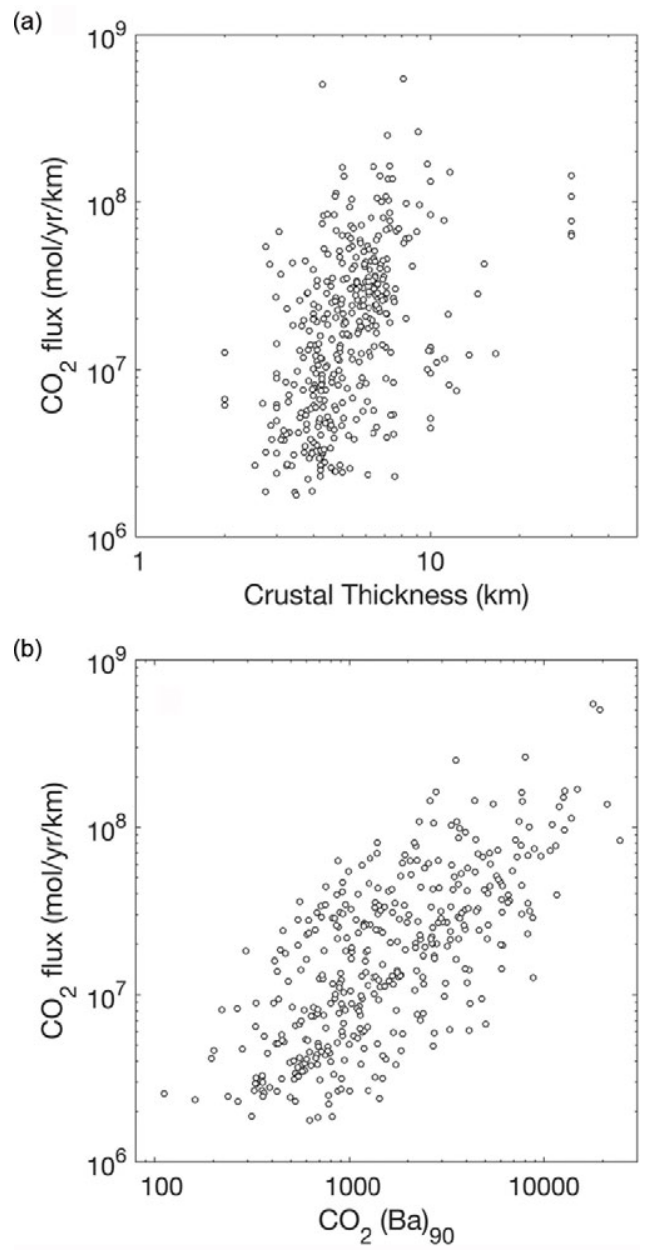

Figure 9.8 MORB segment-average $\mathrm{CO}_{2}$ flux normalized by ridge length ( $\mathrm{mol} / \mathrm{yr} / \mathrm{km}$ ) versus (a) crustal thickness and (b) primary $\mathrm{CO}_{2}$ concentration estimated from the average $\mathrm{MORB} \mathrm{CO} / \mathrm{Ba}$ ratio (81.3) and segment-average $\mathrm{Ba}_{90}$ concentrations. ${ }^{47}$ Estimated $\mathrm{CO}_{2}$ fluxes are more strongly correlated with mantle composition than with crustal thickness.

\subsection{Fluxes of $\mathrm{CO}_{2}$ from Mantle Plumes}

The next most important flux of $\mathrm{CO}_{2}$ from the convecting mantle occurs at intraplate hot spots, where deeper sources of carbon penetrate through the upper mantle and oceanic lithosphere to produce seamounts and volcanic chains (Figure 9.1c). The flux of carbon from the deep mantle is of critical importance to mantle geochemistry and the study of planetary volatiles. Whereas mid-ocean ridges sample the uppermost mantle, some ocean intraplate volcanics sample the deeper mantle via upwelling plumes, ${ }^{97,98}$ which could represent a significant reservoir of terrestrial carbon and other volatile elements. Hot spot magma fluxes are similarly calculated from the volumes of the individual volcanoes in the 
chain; however, weathering of the volcanic edifice and poorer chronologic information on the duration of volcanism result in greater relative uncertainties for these fluxes. The flux of $\mathrm{CO}_{2}$ from oceanic intraplate volcanics is generally considered to be much smaller than the mid-ocean ridge flux. ${ }^{7,10,99}$ However, many oceanic intraplate volcanics erupt subaerially, so their $\mathrm{CO}_{2}$ emissions are injected directly into the atmosphere. Furthermore, many modern-day plumes are linked to LIPs, ${ }^{100}$ and gas emissions from eruption of these OIB progenitors can have profound and devastating environmental effects. ${ }^{101}$

Modern-day volatile fluxes can be directly measured at active volcanic centers by analysis of volcanic gas, and this subject is discussed in depth in Chapter 8. Here, we focus on quantification of long-term integrated fluxes from oceanic intraplate volcanics. These are most typically quantified by combining estimates of primary magmatic $\mathrm{CO}_{2}$ concentrations with magmatic fluxes. Two broad strategies are used to estimate predegassing $\mathrm{CO}_{2}$ concentrations: using maximum measured $\mathrm{CO}_{2}$ concentrations; and using a degassing model to calculate pre-degassing concentrations. The disadvantage of using degassing models is that they require additional constraints such as noble gas or carbon isotopic measurements to quantify the extent of gas loss, and the results may be sensitive to the assumed degassing model and its physical parameters. Using maximum measured values estimated from melt inclusions does not require assumptions about degassing processes, but can only provide lower limits on pre-degassing concentrations.

The heat flux produced by oceanic intraplate hot spots amounts to only $6-10 \%$ of the total surface heat flux; ${ }^{102,103}$ however, OIB magmas produced at hot spots are known to have enriched abundances of volatile elements ${ }^{104-107}$ that may contribute to a $\mathrm{CO}_{2}$ flux in excess of that inferred from their relative heat fluxes. However, enriched $\mathrm{CO}_{2}$ contents can also result in deeper degassing of $\mathrm{CO}_{2}$ and thus many submarine-erupted OIBs have likely lost a greater fraction of their initial $\mathrm{CO}_{2}$ compared with MORBs erupted under the same submarine water pressures. ${ }^{108}$ As a result, like the situation for MORBs, submarine glasses at hot spots have lost the majority of their $\mathrm{CO}_{2}$.

Melt inclusions once again provide the means to examine the $\mathrm{CO}_{2}$ content of OIB magmas. The recent study of Marske and Hauri ${ }^{60}$ provides a definitive data set of volatiles in Hawaiian melt inclusions, adding to the smaller datasets of Refs. 109-111. However, for $\mathrm{CO}_{2}$, these prior studies were all complicated by the presence of vapor bubbles within melt inclusions, which were not accounted for in determining inclusion $\mathrm{CO}_{2}$ concentrations. Tucker et al. ${ }^{61}$ examined hundreds of bubbles in Hawaiian melt inclusions and quantified the uncertainties associated with reconstructing total (bubble + dissolved) $\mathrm{CO}_{2}$ in the melt inclusions. Given the proportion of bubble/inclusion volume (which strongly peaks at $3.3 \%$ for Hawaiian inclusions; Figure 9.4), an estimate of the bubble formation pressure determined from the dissolved $\mathrm{H}_{2} \mathrm{O}$ and $\mathrm{CO}_{2}$ contents of the glass phase, a bubble closure temperature, and an equation of state for $\mathrm{CO}_{2}$ vapor, it is possible to reconstruct the total $\mathrm{CO}_{2}$ content of the inclusion. At Hawaii, these $\mathrm{CO}_{2}$ contents range over hundreds of ppm to several wt. $\% \mathrm{CO}_{2}$; however, much of this range is likely due to degassing, and only the highest $\mathrm{CO}_{2}$ contents are likely to be representative of primary (undegassed) $\mathrm{CO}_{2}$ contents . Tucker et al. ${ }^{61}$ estimated an average primary Hawaiian magma $\mathrm{CO}_{2}$ content of $7000 \mathrm{ppm}$ 
Table 9.1 Melt inclusion-based estimates for primary magma $\mathrm{CO}_{2}(\mathrm{ppm})$ and $\mathrm{CO}_{2}$ fluxes from selected oceanic intraplate hot spots

\begin{tabular}{llllllll}
\hline \hline Locality & Iceland & Azores & Canary & Hawaii & Society & Pitcairn & Total \\
\hline $\begin{array}{l}\text { Number of MIs } \\
\text { Primary } \mathrm{CO}_{2}\end{array}$ & 104 & 26 & 29 & 407 & N/A & N/A & \\
(ppm) & 3200 & 8200 & 10,600 & 7000 & 14,000 & 5100 & \\
Magma supply & $5.40 \mathrm{E}+13$ & $2.67 \mathrm{E}+12$ & $2.70 \mathrm{E}+12$ & $5.40 \mathrm{E}+14$ & $6.75 \mathrm{E}+12$ & $1.62 \mathrm{E}+13$ & \\
rate (g/yr) & & & & & & & \\
$\mathrm{CO}_{2}$ flux (g/yr) & $1.73 \mathrm{E}+11$ & $2.19 \mathrm{E}+10$ & $2.86 \mathrm{E}+10$ & $3.78 \mathrm{E}+12$ & $9.45 \mathrm{E}+10$ & $8.26 \mathrm{E}+10$ & $4.18 \mathrm{E}+12$ \\
$\mathrm{C} \mathrm{flux}(\mathrm{Tg} / \mathrm{yr})^{4.71 \mathrm{E}-02}$ & $5.97 \mathrm{E}-03$ & $7.81 \mathrm{E}-03$ & $1.03 \mathrm{E}-00$ & $2.58 \mathrm{E}-02$ & $2.25 \mathrm{E}-02$ & $1.14 \mathrm{E}+00$ \\
$\mathrm{CO}_{2}$ flux & $3.93 \mathrm{E}+09$ & $4.98 \mathrm{E}+08$ & $6.5 \mathrm{E}+08$ & $8.59 \mathrm{E}+10$ & $2.15 \mathrm{E}+09$ & $1.88 \mathrm{E}+09$ & $9.50 \mathrm{E}+10$ \\
(mol/yr) & & & & & & & \\
Refs. & $64,65,180$ & 62,180 & 63,180 & 61,181 & 117 & 116 & \\
\hline \hline
\end{tabular}

$\mathrm{MI}=$ melt inclusion; N/A = not applicable.

(Table 9.1) and a modern $\mathrm{CO}_{2}$ flux for Hawaii of $8.6 \times 10^{10} \mathrm{~mol} / \mathrm{yr}$. This flux represents approximately $5 \%$ of the MORB $\mathrm{CO}_{2}$ flux, ${ }^{47}$ while the magma flux at Hawaii $\left(0.2 \mathrm{~km}^{3} / \mathrm{yr}\right)$ represents only $1 \%$ of the MORB magma flux, a comparison that highlights the enriched nature of $\mathrm{CO}_{2}$ in Hawaiian magmas.

The melt inclusion-based estimates compare well to prior published estimates of Hawaiian magma primary $\mathrm{CO}_{2}$ contents and volcanic fluxes. By combining dissolved and vesicular $\mathrm{CO}_{2}$ concentrations, Dixon and Clague ${ }^{104}$ found maximum $\mathrm{CO}_{2}$ concentrations of up to $6300 \mathrm{ppm}$ in submarine Loihi basalts. Using a noble gas-based disequilibrium degassing model, Gonnermann and Mukhopadhyay ${ }^{112}$ estimated pre-degassing concentrations of between 1100 and $6300 \mathrm{ppm}$ in basalts from Loihi and Kilauea. However, those results may be sensitive to model parameters such as the magmatic carbon diffusivity. The long-term rate from melt inclusions is similar to modern-day emission rates measured from the Kilauea summit. ${ }^{13-115}$

Given knowledge of the $\mathrm{H}_{2} \mathrm{O}$ and $\mathrm{CO}_{2}$ contents of glassy melt inclusions and vapor bubble sizes, the same methodology as applied to the Hawaiian inclusions can also be applied to published data sets from other hot spots in order to calculate their primary magma $\mathrm{CO}_{2}$ contents and $\mathrm{CO}_{2}$ fluxes. Melt inclusion volatile and bubble size data are available from the Azores, ${ }^{62}$ Canary, ${ }^{63}$ and Iceland ${ }^{64,65}$ hot spots; primary magmatic $\mathrm{CO}_{2}$ contents of these hot spots are conservatively estimated as the 95th percentile of $\mathrm{CO}_{2}$ contents from the data sets. Additionally, we include estimates based on analyses of submarine glasses of the Society and Pitcairn hot spots. ${ }^{116,117}$ The primary $\mathrm{CO}_{2}$ contents of these hot spot OIBs range from $3200 \mathrm{ppm}$ at Iceland to $10,600 \mathrm{ppm} \mathrm{CO}_{2}$ at the Canaries, suggesting a large degree of heterogeneity in primary $\mathrm{CO}_{2}$ contents between hot spots (Table 9.1). However, each of the individual $\mathrm{CO}_{2}$ fluxes of the smaller hot spots is more than an order of magnitude lower than the $\mathrm{CO}_{2}$ flux from Hawaii.

In their bathymetric studies of Pacific seamounts and islands, Batiza, ${ }^{118}$ Wessel and Lyons, ${ }^{119}$ and Kim and Wessel ${ }^{120}$ estimated the total volume of oceanic intraplate magmatism 
to be $1-2 \times 10^{7} \mathrm{~km}^{3}$, which equates to an extra 100-200 m (1.5-3.0\%) of crustal thickness across the entirety of the Pacific plate. If this relationship holds for all of the ocean basins, then even with a primary magma $\mathrm{CO}_{2}$ content of $1 \mathrm{wt} . \%$ (similar to the highest OIB primary $\mathrm{CO}_{2}$ contents; Table 9.1), this would represent an additional 12-25\% atop the ridge flux, or $0.17-0.35 \times 10^{12} \mathrm{~mol} / \mathrm{yr}$ (or two to four times the output of Hawaii; Table 9.1). Thus, while the overall intraplate $\mathrm{CO}_{2}$ output is not insignificant compared with the ridge flux, long-term global variations in the $\mathrm{CO}_{2}$ flux from ridges alone are no doubt of a similar magnitude given the spreading rates and total ridge length changes during plate tectonic evolution. And because most of the intraplate volcanism in the oceans is below sea level, the $\mathrm{CO}_{2}$ outgassed at all but the largest hot spots is fated for dissolution into seawater, and, like the MORB flux, it is ultimately precipitated as carbonate sediments and carbonate vein fillings on the seafloor.

LIPs represent an exceptional source of hot spot-related magmatism due to their punctuated eruptions of enormous volumes over very short periods of time ( 1 Myr) that approach the global MORB production rate and the well-known correlation of ages of LIP eruption events with the timing of mass species extinctions. ${ }^{121-122}$ Such eruptions have great potential to influence global climate on short timescales due to the likelihood that their volatile inventory was delivered directly to the atmosphere; this is particularly acute for the emission of $\mathrm{SO}_{2}$ during LIP volcanism, as the atmospheric abundance of $\mathrm{SO}_{2}$ is typically low and its ability to absorb or reflect UV radiation is very high. Thus, LIP $\mathrm{SO}_{2}$ emissions (of the order $10^{13} \mathrm{~mol} / \mathrm{yr}$ over decadal timescales) are enormous compared with the $\mathrm{SO}_{2}$ budget of the atmosphere (of the order $10^{10} \mathrm{~mol} / \mathrm{yr}$ ) and can result in severe shortterm cooling effects on Earth's surface. ${ }^{16,121}$ If flood basalts contain primary $\mathrm{CO}_{2}$ contents similar to OIBs, the emission of $\mathrm{CO}_{2}$ in a single decade-long eruption potentially represents a magnitude of the order $10^{13} \mathrm{~mol} / \mathrm{yr},{ }^{16}$ approximately ten times the modern emission rate from mid-ocean ridges ${ }^{47}$ and representing an instantaneous decadal addition to atmospheric $\mathrm{CO}_{2}$ on the order of $1000 \mathrm{ppm}$. The greenhouse effect of such LIP $\mathrm{CO}_{2}$ emissions would be concurrent with LIP $\mathrm{SO}_{2}$ emissions. Increased $\mathrm{SO}_{2}$ would push conditions toward global cooling, but would have a shorter residence time in the atmosphere than $\mathrm{CO}_{2}$. Thus, the overall impact of LIP volcanism might be expected to strongly drop global temperatures while the volcanism is active and to strongly increase global temperatures following the cessation of eruptions. The evolution of end-member "hothouse" or "icehouse" climate conditions, triggered by LIP eruptions, could depend on whether the atmospheric system was already close to a tipping point in one direction or the other. ${ }^{16,122,126}$ Nevertheless, both $\mathrm{SO}_{2}$ and $\mathrm{CO}_{2}$ emissions from LIPs would ultimately lead to intense ocean acidification that could be an additional driver in triggering mass extinctions associated with LIP volcanism.

\subsection{Carbon Content of Convecting Mantle Sources}

The large range of primary MORB and OIB magma $\mathrm{CO}_{2}$ contents at the segment scale is due to a combination of variations in degree of melting, as well as variations in mantle $\mathrm{CO}_{2}$ 
abundance. The mean degree of melting at a given ridge segment can be evaluated by consideration of crustal thickness. For the standard model of passive upwelling at oceanic spreading centers, Klein and Langmuir ${ }^{20}$ describe the relationships between crustal thickness $\left(D_{c}\right)$, mean degree of melting $(\bar{F})$, mean pressure of melting $(\bar{P})$, and final pressure of melting $\left(P_{f}\right)$. The mean degree of melting can be calculated from the crustal thickness using the following relation:

$$
\bar{F}=0.006 \sqrt{D_{c} \rho_{c} / 0.0612}
$$

where crustal thickness $D_{c}$ has units of kilometers and $\rho_{c}$ is the density of the oceanic crust in units of $\mathrm{Tg} / \mathrm{km}^{3}$ (equivalent to $\mathrm{g} / \mathrm{cm}^{3}$ ). With estimates of crustal thickness for each ridge segment derived from its relationship with ridge depth, we can use (9.1) to calculate the degree of melting at each segment and then invert the primary $\mathrm{CO}_{2}$ content for mantle $\mathrm{CO}_{2}$ using the batch melting equation:

$$
C_{\text {mantle }}=C_{\text {melt }}\left[D_{\text {carbon }}(1-\bar{F})+\bar{F}\right],
$$

where $C_{\text {mantle }}$ is the mantle concentration, $C_{\text {melt }}$ is the melt concentration (in equilibrium with $\mathrm{Fo}_{90}$ olivine), and $D_{\text {carbon }}$ is the carbon bulk solid/melt partition coefficient. Because $D_{\text {carbon }}$ is much lower than $\bar{F},(9.2)$ reduces to a simple relationship between the degree of melting and mantle-melt concentrations:

$$
C_{\text {mantle }}=C_{\text {melt }} \bar{F} \text {. }
$$

Bearing in mind that the accuracy of the primary $\mathrm{CO}_{2}$ in MORB contents relies on our assumption that $\mathrm{CO}_{2} / \mathrm{Ba}$ and $\mathrm{CO}_{2} / \mathrm{Rb}$ are relatively invariant, we can use (9.3) to calculate mantle source concentrations of $\mathrm{CO}_{2}$ at each ridge segment. The calculations, carried out in the dataset of Cottrell et al. (2019), ${ }^{183}$ predict that MORB mantle $\mathrm{CO}_{2}$ content ranges over two orders of magnitude from 10 ppm (segment GALA16) to 1980 ppm (segment JUAN1; Figure 9.9) and follows a log-normal distribution. For the 387 segments with trace element constraints, we estimate that the mean mantle $\mathrm{CO}_{2}$ content is $205 \mathrm{ppm}$, the median is $99 \mathrm{ppm}$, and the mode (estimated using a kernel density analysis as above), is $73 \mathrm{ppm}$. Segmentspecific values are tabulated in Cottrell et al. (2019). ${ }^{183}$ If we assume that the segments without trace element constraints have "typical" primary melt $\mathrm{CO}_{2}$ contents, constrained by either the distribution mode (621 ppm) or the median (1107 ppm), then the mode of mantle $\mathrm{CO}_{2}$ distribution is 50 or $104 \mathrm{ppm}$, respectively. The Arctic ridges are noteworthy in having uniformly high estimates of mantle $\mathrm{CO}_{2}$. There are additional isolated ridge segments with high estimated mantle $\mathrm{CO}_{2}$ concentrations that are far from hot spots, notably just north of the equatorial Mid-Atlantic Ridge (MARR168), much of the American-Antarctic Ridge, several slow-spreading segments of the Southwest Indian Ridge, and the northernmost Red Sea. Apart from these scattered locations, there is a strong geographic correlation of high mantle $\mathrm{CO}_{2}$ at ridge segments that occur near hot spots (Iceland, Azores, South Atlantic hot spots, Reunion, Afar, Easter Island, Galapagos). All of the ridge segments with $>700 \mathrm{ppm}$ mantle $\mathrm{CO}_{2}$ are located within $1000 \mathrm{~km}$ of the nearest hot spot, which may indicate that hot 


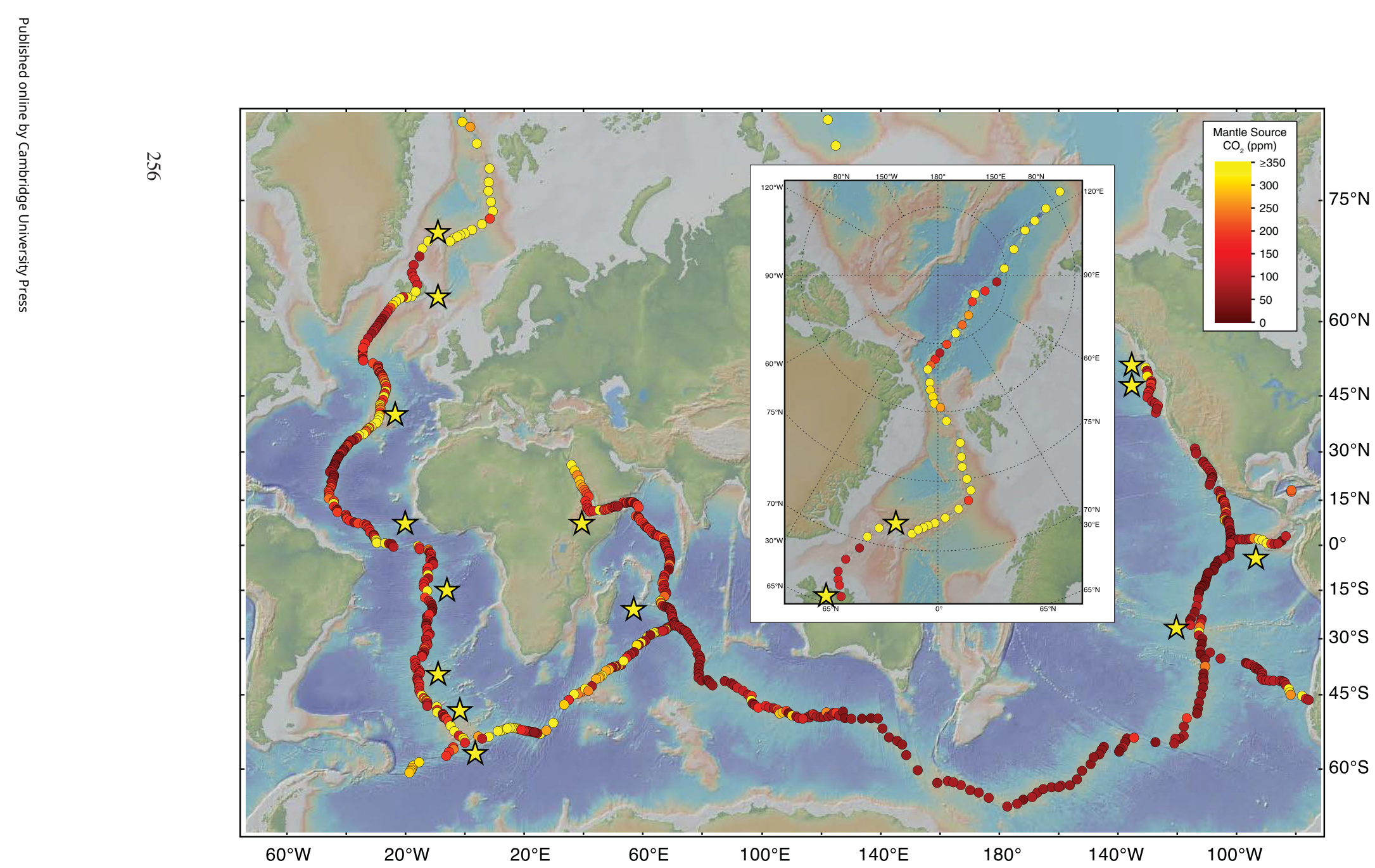

Figure 9.9 Map of segment-average mantle source $\mathrm{CO}_{2}$ concentrations along the global mid-ocean ridge system. Mantle source $\mathrm{CO}_{2}$ concentrations were derived from segment-average primary $\mathrm{CO}_{2}$ abundances by estimating the degree of melting at each ridge segment and assuming batch melting (see Eqs. (9.1)-(9.3) in the text). High concentrations are observed near hot spots (yellow stars show approximate localities but are off-set so as to not obscure data), but also at isolated sections of ridge far from hot spots, particularly the Arctic ridges and the southern Indian Ocean ridges. 
spots have elevated concentrations of $\mathrm{CO}_{2}$ in their mantle sources. This inference is predicated on our underlying assumption that the mantle has uniform $\mathrm{CO}_{2} / \mathrm{Ba}$ and $\mathrm{CO}_{2} / \mathrm{Rb}$ ratios. ${ }^{47,53}$ If hot pots sample recycled mantle that has had carbon added to it or stripped from $\mathrm{it}^{7,8}$ relative to other trace elements, our assumption would not hold and our inferences about primary $\mathrm{CO}_{2}$ at hot spots would not be valid. While this is an important topic for future inquiry, at this point there is no evidence to suggest that the $\mathrm{CO}_{2} / \mathrm{Ba}$ or $\mathrm{CO}_{2} / \mathrm{Rb}$ ratios at hot spots are significantly different from those of the MORB mantle. ${ }^{53}$

At hot spots, no simple relationship translates between volcano volume and degree of melting, as hot spots have widely different temperatures and buoyancy fluxes ${ }^{127,128}$ and erupt through oceanic lithosphere of widely variable age and thickness. Thus, the degree of melting must be determined in a different way from MORBs. Estimates of the degree of melting for the major Hawaiian volcanoes range from $\sim 4 \%$ to $10 \%,{ }^{129,130}$ which, when combined with estimates of primary $\mathrm{CO}_{2}$ contents of individual volcanoes, yield mantle $\mathrm{CO}_{2}$ concentrations ranging from $\sim 400$ to $500 \mathrm{ppm} .^{61}$

Other hot spots appear to produce magmas that have high primary $\mathrm{CO}_{2}$ concentrations similar to Hawaii. Barry et al. ${ }^{131}$ estimated a $\mathrm{CO}_{2}$ concentration for the Iceland plume of 530 ppm, which is similar to the 590 ppm CO$~_{2}$ estimated by Le Voyer et al. ${ }^{47}$ for the most $\mathrm{CO}_{2}$-rich ridge segment at Iceland. Similarly, high mantle $\mathrm{CO}_{2}$ contents are observed at hot spotproximal ridge segments near Jan Mayen (1800 ppm), the Azores (1490 ppm), Cape Verde (830 ppm), Ascension (415 ppm), Discovery/Meteor (910 ppm), Shona (480 ppm), Bouvet (1160 ppm), Reunion (415 ppm), Afar (1420 ppm), Easter Island (350 ppm), Galapagos (850 ppm), and the Bowie hot spot on the Juan de Fuca Ridge (1980 ppm). At intraplate hot spots, mantle $\mathrm{CO}_{2}$ concentrations in the Society and Pitcairn hot spots have been estimated to be 700 $\mathrm{ppm}^{117}$ and between 260 and $510 \mathrm{ppm},{ }^{116}$ respectively. Despite the highly variable methods used, these hot spot mantle $\mathrm{CO}_{2}$ concentrations are distinctly higher than mantle concentrations at nearly all MORB ridge segments located $>1000 \mathrm{~km}$ away from hot spots. ${ }^{47}$

\subsection{Carbon and Mantle Melting}

Partial melting of the convecting mantle beneath ridges and hot spots is the key process and pathway by which carbon moves from Earth's interior to the surface. ${ }^{7,8,132,133}$ Thus far in this chapter, we have addressed the quantity and dynamic range of carbon present in the mantle and how it partitions between the crust and hydrosphere. We now explore carbon's role in mantle melting and how it affects the flux of carbon reaching the ridge axis.

Decompression melting above the anhydrous solidus dominates the production of melt and oceanic crust at ridges. ${ }^{134}$ However, the volume of mantle that experiences low degrees of partial melting far exceeds the volume above the anhydrous solidus and depends on the power of volatiles, primarily $\mathrm{H}_{2} \mathrm{O}$ and $\mathrm{CO}_{2}$, to flux mantle melting. ${ }^{135-137}$ Dasgupta $^{138}$ provides an in-depth review and further exploration of near-solidus mantle melting in the presence of $\mathrm{H}_{2} \mathrm{O}$ and $\mathrm{CO}_{2}$. Here, we keep the focus on carbon and how its dynamic range in the mantle source relates to the flux of carbon reaching the ridge axis. 
Three fundamental properties of carbon affect its fate during partial melting: (1) carbon is highly incompatible in mantle silicates, $;^{78,139,140}$ (2) carbon is likely to exist in both oxidized and reduced forms within Earth's mantle $;^{7,141-147}$ and (3) oxidized carbon stabilizes melts, influencing the partial melting process itself. ${ }^{132,133,137,148-151}$ In mantle where oxygen fugacity $\left(f \mathrm{O}_{2}\right)$ is low enough to stabilize graphite, carbon concentration in silicate melts, and hence the flux of carbon to the surface, will vary as a function of $f_{2}$, temperature, and pressure. ${ }^{145,152-154}$ Depending on the concentration of carbon in the source and degree of melting, graphite may be exhausted from the source during decompression melting under reduced conditions at quite low melt fractions. ${ }^{155}$ Such conditions may be relevant on reduced terrestrial bodies, such as Mars, but on Earth, basalts ${ }^{156-159,184}$ and their residues ${ }^{160}$ record $f \mathrm{O}_{2}$ near the quartz-fayalite-magnetite (QFM) buffer and are too oxidized to stabilize graphite in their residues.

In a uniformly oxidized mantle, the stable form of carbon is carbonate. The solidus of carbonated peridotite is depressed by hundreds of degrees relative to the anhydrous solidus, ${ }^{132}$ is nearly independent of carbon concentration, ${ }^{161}$ and is sufficiently steep to allow carbonatitic melts to form all the way to the transition zone along convecting mantle geotherms. ${ }^{162}$ The flux of carbon from the mantle to the surface in this scenario depends on the concentration of carbon in the source, with carbonatitic $\left(\sim 40 \mathrm{wt} . \% \mathrm{CO}_{2}\right)$ melts forming at melt fractions proportional to carbon concentration. The melt fraction across the carbonated solidus for a MORB mantle with median $\mathrm{CO}_{2}(\sim 100 \mathrm{ppm})$ would be $0.03 \%$, but could range from $0.0025 \%$ to $0.5 \%$ spatially, consistent with the dynamic range of mantle $\mathrm{CO}_{2}$ contents predicted here (10-2000 ppm). The addition of water to the system may stabilize carbonated silicate melts over carbonatitic melts to hundreds of kilometers; ${ }^{137,138}$ however, consideration of silica activity-composition relationships at greater depths predicts an abrupt transition from carbonatitic to carbonated silicate melts as shallow as $75-100 \mathrm{~km}$ along a $1350^{\circ} \mathrm{C}$ geotherm. ${ }^{151}$ Regardless of the melt composition, in a uniformly oxidized mantle, deep carbon-rich melts would be widespread, but heterogeneously distributed at depth if mantle carbon concentrations are as variable as suggested by Le Voyer et al. ${ }^{47}$

A uniformly oxidized mantle is unlikely on Earth, however. Theoretical and experimental considerations and observational evidence from continental xenoliths all suggest that the mantle becomes more reducing with depth relative to the QFM buffer. ${ }^{142,146,163-167}$ When $f \mathrm{O}_{2}$ becomes low enough to stabilize graphite/diamond over carbonate, carbonate-fluxed melting cannot proceed. The depth of the carbonate-graphite/ diamond transition is uncertain, but may lie as shallow as $120 \mathrm{~km}$ due to increasing stabilization of the ferric iron component in garnet with pressure, ${ }^{167}$ or perhaps at depths closer to $250 \mathrm{~km}$ due to increasing modes of majoritic garnet and stabilization of $\mathrm{Fe}$ metal. ${ }^{166}$ It should be noted that the xenolith record of iron redox comes entirely from continental lithospheric xenoliths rather than oceanic samples; thus, our limited knowledge of the redox-depth profile of the convecting mantle stands as a major limitation to our ability to predict the extent and consequences of carbon-fluxed melting at depth.

If we assume that the mantle becomes reduced quickly with depth and that the carbonate to graphite transition takes place at $120 \mathrm{~km}$ depth, then this depth will correspond to the 
depth of incipient melting. The depth at which melts are not only present, but interconnected and detectable with geophysical probes, will depend on carbon concentration. If we assume a threshold for melt interconnectivity and detection of 0.05 wt. $\%$ melt, ${ }^{168}$ then Le Voyer et al. ${ }^{52}$ showed how minimum $\mathrm{CO}_{2}$ concentrations of $\sim 85 \mathrm{ppm}$ are required at $120 \mathrm{~km}$ depth to generate detectable melts in anhydrous mantle with a potential temperature of $1345^{\circ} \mathrm{C}$. The depth of interconnected, detectable melting will decrease as carbon concentration decreases. As the depth of the carbonate-graphite/diamond transition deepens, the importance of carbon concentration to the volume of mantle interconnected by melts increases. However, so long as mantle carbon concentrations are above 220 ppm, melts will be interconnected and detectable at all depths and carbon will be extracted as soon as the mantle becomes oxidized enough to stabilize carbonate, provided those melts can reach the ridge axis (see below). Thus, the depth range over which carbon-fluxed melting creates important geophysical signatures and actively increases the flux of carbon to the surface by enabling melting itself may be narrow. Indeed, in a mantle with only $140 \mathrm{ppm}$ water, there may be no depth range over which carbon concentration strongly influences such signatures because of water's ability to contribute to melt stabilizations. ${ }^{138,169}$

While the $f \mathrm{O}_{2}$ recorded by ridge lithologies suggests that the MORB source is too oxidized to retain graphite as a stable residual phase, the high concentration of $\mathrm{CO}_{2}$ dissolved in undegassed MORB provides further independent evidence of this. Figure 9.10 shows the extent of melting required to exhaust graphite during peridotite melting in the graphite stability field as a function of $f \mathrm{O}_{2}$ and the carbon content of the mantle (100 ppm $\mathrm{CO}_{2}$ corresponds to $27 \mathrm{ppm} \mathrm{C}$ ). The $\mathrm{fO}_{2}$ range for graphite/diamond stability in the mantle corresponds to depths greater than $100 \mathrm{~km}$ and is taken from Stagno et al. ${ }^{167}$ For typical mantle with $\sim 50-100 \mathrm{ppm} \mathrm{CO}_{2}(=14-27 \mathrm{ppm} \mathrm{C})$, graphite would be exhausted at reasonable melt fractions for MORBs (6-20\%). In this scenario, we would expect carbon to behave as a highly incompatible element, just as we observe in some submarine glass and melt inclusion suites that are undersaturated in $\mathrm{CO}_{2}-\mathrm{H}_{2} \mathrm{O}$ vapor. ${ }^{49-53}$ However, at higher mantle $\mathrm{C}$ contents, such as are evidenced by Le Voyer et al. ${ }^{47}$ and presented here, melt fractions far in excess of $20 \%$ would be required to exhaust $\mathrm{C}$ from the residue and produce incompatible behavior for carbon. Such high melt fractions are unreasonable for MORB. Lower melt fractions would leave graphite (or diamond) present in the residue, and carbon would appear to behave as a moderately incompatible element, quite unlike the highly incompatible behavior seen in vapor-undersaturated MORB samples. Although there is a lack of detailed understanding of the $f \mathrm{O}_{2}$ with depth in the convecting mantle, the discovery of vapor-undersaturated samples at higher total carbon contents might illuminate whether or not graphite/diamond-saturated melting is an important process to consider at the deepest parts of the melting regime beneath ridges and hot spots.

Thus far, we have considered uniform partial melting, melt interconnectivity, and melt extraction. Keller et al. ${ }^{133}$ show how melt focusing is only effective within and below the width defined by the anhydrous melting triangle, and that this may impact the fraction of mantle carbon in the melting regime that reaches the ridge axis. They show that deep volatile-fluxed melting may not influence melt focusing to the extent previously 


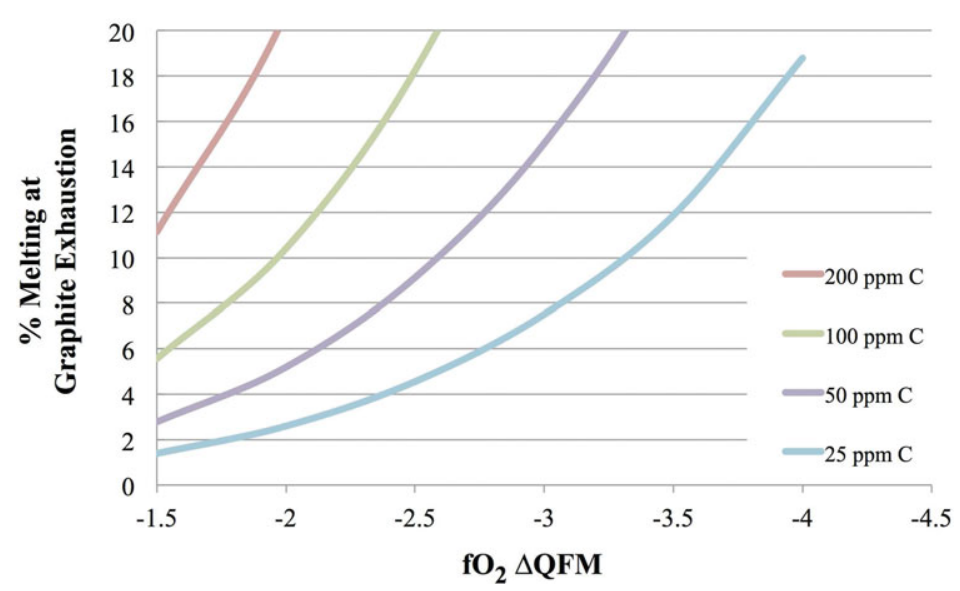

Figure 9.10 Extent of melting required to exhaust graphite from the mantle as a function of the $f_{2}$ and the $\mathrm{C}$ content of the mantle. The solubility of total $\mathrm{C}$ in graphite-saturated silicate melt was taken from experimental studies. ${ }^{145,153,154}$ At low mantle C contents, only small degrees of melting would be required to exhaust graphite, and $\mathrm{C}$ would behave similarly to highly incompatible elements (D 0.02-0.04). At higher mantle $\mathrm{C}$ contents, $\mathrm{C}$ would appear only mildly incompatible (D 0.1-0.2). For typical MORB melt fractions, we observe that $\mathrm{C}$ behaves as a highly incompatible element in vapor-undersaturated melt inclusions. This provides independent evidence that the MORB source is not graphite saturated; however, these curves could be relevant when considering more reduced planetary bodies, such as Mars.

assumed, ${ }^{136}$ but instead introduces spatial and temporal variability in the volatile flux reaching the ridge on timescales of 10,000 years. Keller et al. ${ }^{133}$ predict that the concentrations of carbon (or any incompatible element) in primary MORB melts could vary as a function of time for any given source concentration due to reactive channelization. Furthermore, melts generated in the "wings" of the melt triangle collect along the base of the lithosphere and ultimately freeze, and up to half the melt volume produced within the melting regime may never make it to the surface at the ridge axis. ${ }^{133}$ Because such melts do not contribute to oceanic crust production, their contribution does not factor into estimates of $\mathrm{CO}_{2}$ fluxes derived from geochemical and geophysical observations. The important implication for what we have presented here is that much of the heterogeneity we observe in incompatible trace elements on the dredge scale (hundreds of meters) within MORB may be generated by the melting process, rather than very-fine-scale variations in mantle source. ${ }^{170}$ Thus, when interpreting our segment-scale variations in mantle source globally, we must keep in mind how representative the concentrations presented here may be for poorly sampled segments and recognize that within segments it can be difficult to distinguish time-dependent variations in process from small-scale variations in composition.

Keller et al. ${ }^{133}$ and Le Voyer et al. ${ }^{47}$ provide the only estimates of segment-specific carbon flux. MORB mantle from Le Voyer et al. ${ }^{47}$ has $\sim 73$ ppm (mode), 99 ppm (median) 
$\mathrm{CO}_{2}$ in the sources. ${ }^{183}$ For such sources, the model of Keller et al. ${ }^{133}$ returns global fluxes of $9.4 \times 10^{6}$ to $1.3 \times 10^{7} \mathrm{~mol} / \mathrm{yr} / \mathrm{km}$ (normalized to ridge length), which is comparable to the $1.4 \times 10^{7} \mathrm{~mol} / \mathrm{yr} / \mathrm{km}$ estimated in Le Voyer et al. ${ }^{47}$ and this study. These lengthnormalized ridge fluxes are in excellent agreement despite the facts that Keller et al. ${ }^{133}$ use a constant-source $\mathrm{CO}_{2}$ content and that the two models calculate crustal thicknesses differently. The average crust is $0.83 \mathrm{~km}$ thicker in the model output of Keller et al., ${ }^{133}$ who modeled magma production at variable potential temperatures constrained from a global-scale seismic tomography model, ${ }^{171}$ producing a mean crustal thickness of $6.67 \mathrm{~km}$. Le Voyer et al. ${ }^{47}$ used the relationship of crustal thickness versus ridge depth observed at ridges with seismically determined crustal thickness measurements and extrapolated this relationship to calculate crustal thickness at all ridge segments from their axial depth, producing an average crustal thickness of $5.75 \mathrm{~km}$ despite calculating larger crustal thicknesses at hot spots compared with Keller et al., ${ }^{133}$ who capped their temperature input values at $1450^{\circ} \mathrm{C}$.

When integrated over the entire length of ridges, we ${ }^{183}$ calculate a global $\mathrm{CO}_{2}$ flux of 1.3 to $1.5 \times 10^{12} \mathrm{~mol} / \mathrm{yr}$, depending on whether the global mode or median $\mathrm{CO}_{2}$ content is applied to segments unconstrained by trace element data. Keller et al. ${ }^{133}$ calculate a global flux of $1.20 \times 10^{12} \mathrm{~mol} / \mathrm{yr}$. Despite the differences in methodology, these two studies are in excellent agreement on the integrated ridge $\mathrm{CO}_{2}$ flux, and this agreement emphasizes the depth of our understanding of $\mathrm{CO}_{2}$ fluxes at ridges.

At the same time, mantle heterogeneity must be considered at the more granular scale of individual ridge segments. Figure 9.11 highlights the geographic distribution of differences in segment-scale $\mathrm{CO}_{2}$ fluxes between our estimates, with variable-source $\mathrm{CO}_{2}$, and the Keller et al. ${ }^{133}$ estimates. Observations of $\mathrm{Sr}, \mathrm{Nd}, \mathrm{Pb}$, and $\mathrm{Hf}$ isotopic heterogeneity within individual ridge segments (length scales of tens to hundreds of kilometers) are often observed where measurements are sufficiently dense (see data sets of Gale et al. $^{36}$ and Class and Lehnert ${ }^{172}$ ). It has long been recognized that mantle heterogeneity is the primary source of segment-scale variations in isotopes and highly incompatible trace elements (e.g. Langmuir et al. ${ }^{21}$ ). Keller et al. ${ }^{133}$ show that, for a homogeneous mantle, spreading rate and potential temperature dominate the flux of carbon at ridges, as these parameters dominate the production rate of magma itself. But the ridge $\mathrm{CO}_{2}$ flux is more sensitive to mantle carbon concentration than to mantle temperature, spreading rate, compaction length, or mantle fertility. The segment-scale $\mathrm{CO}_{2}$ fluxes that we have calculated (normalized by segment length) exhibit a variability that is twice that observed in the model of Keller et al.; ${ }^{133}$ in our calculations of crustal thickness, we have implicitly included the effects of mantle temperature and magma production rate, since they also influence crustal thickness. In this rendering, it is clear that consideration of variability in mantle source $\mathrm{CO}_{2}$ concentrations results in much higher carbon fluxes near hot spots and lower carbon fluxes for the D-MORB mantle than those of the Keller et al. ${ }^{133}$ model with a single-source composition. It is also clear that mantle source concentration has more influence on $\mathrm{CO}_{2}$ flux at the ridge than any other parameter under consideration. 


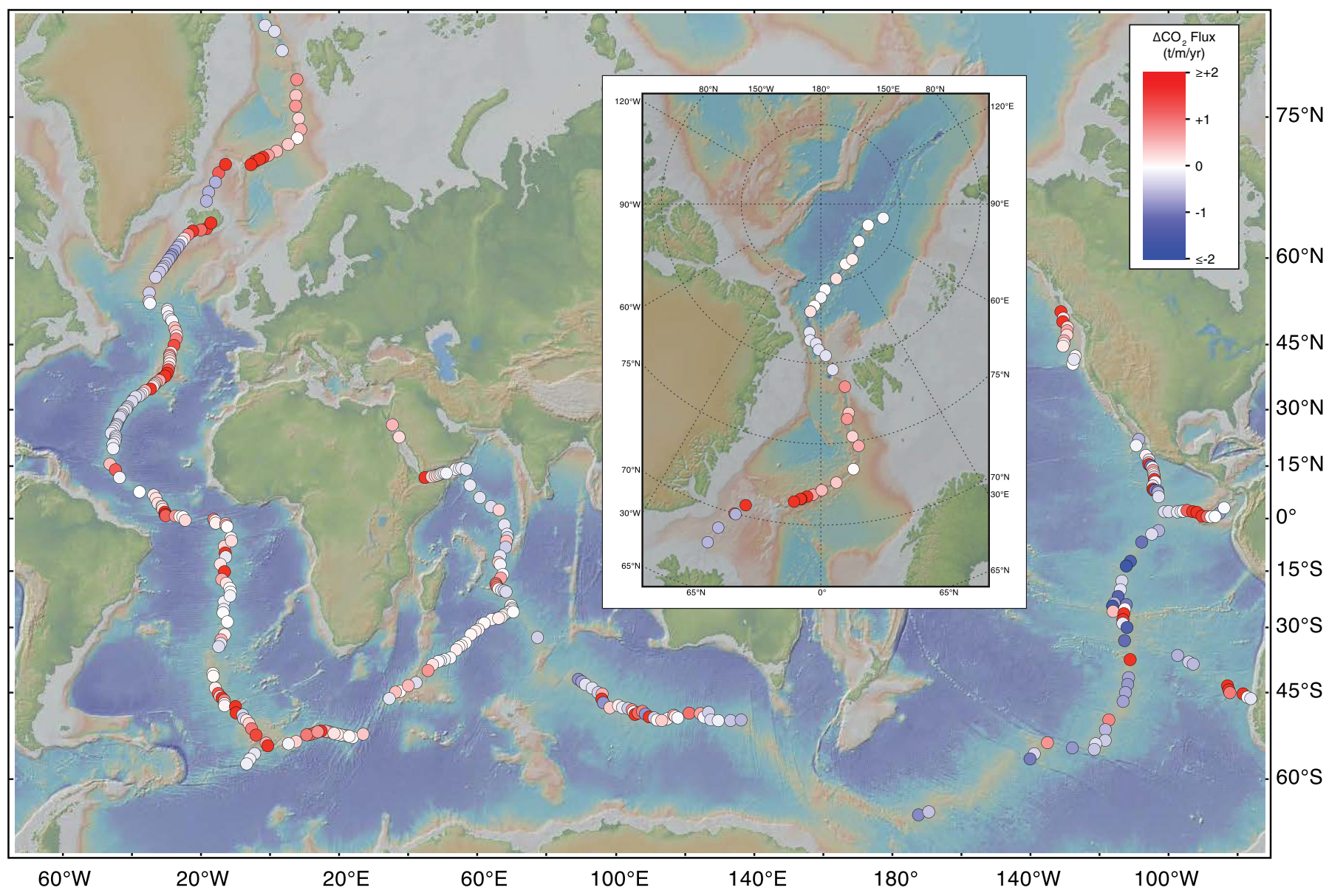

Figure 9.11 Map of differences in segment-scale $\mathrm{CO}_{2}$ fluxes as estimated compared with fluxes calculated from the model of Keller et al. ${ }^{133}$ The main differences are that Keller et al. ${ }^{133}$ use a uniform mantle $\mathrm{CO}_{2}$ content of $100 \mathrm{ppm}$; while we ${ }^{183}$ estimate mantle $\mathrm{CO}_{2}$ contents by calculating primary magma $\mathrm{CO}_{2}$ and degree of melting at each segment, resulting in variations of mantle $\mathrm{CO}_{2}$ of more than three orders of magnitude (Figure 9.8). 


\subsection{Conclusions}

The convecting mantle holds the vast majority of the carbon in the silicate Earth, and melting of this mantle at ridges and hot spots provides a means to assess the behavior of carbon in Earth's interior. Studies of large numbers of samples of submarine volcanic glasses and melt inclusions utilizing accurate and precise high-throughput microbeam methods have uncovered suites of MORB samples that are undersaturated in $\mathrm{CO}_{2}$ and display correlated variations of $\mathrm{CO}_{2}$ with nonvolatile incompatible trace elements, with limited variations in $\mathrm{CO}_{2} / \mathrm{Ba}$ and $\mathrm{CO}_{2} / \mathrm{Rb}$. These valuable sample suites have provided a means to assess the primary $\mathrm{CO}_{2}$ concentrations in MORBs at each ridge segment and to quantify, with stated uncertainties, the segment-scale and total flux of $\mathrm{CO}_{2}$ from mid-ocean ridges. We suggest that $\mathrm{CO}_{2}$ fluxes from the mantle to the surface vary by over three orders of magnitude at the segment scale.

\subsection{Limits of Knowledge and Unknowns}

A key advance in the future will be the discovery of more populations of $\mathrm{CO}_{2}$ undersaturated samples so that the assumed limited variability in $\mathrm{CO}_{2} / \mathrm{Ba}$ and $\mathrm{CO}_{2} / \mathrm{Rb}$ ratios and the origin of the variability of $\mathrm{CO}_{2} / \mathrm{Nb}$ and $\mathrm{CO}_{2} / \mathrm{Th}$ ratios can be critically assessed. It will likewise be advantageous to conduct rare gas and carbon isotope measurements on $\mathrm{CO}_{2}$-undersaturated sample suites in order to assess the degree of possible carbon isotope heterogeneity in the convecting upper mantle. While the knowledge of $\mathrm{MORB}$ mantle $\mathrm{CO}_{2}$ is now quite mature, we still lack the number of demonstrably vapor-undersaturated samples with which to assess one of our primary assumptions regarding MORB magmatism, namely the assumed homogeneity of MORB $\mathrm{CO}_{2} / \mathrm{Ba}$ and $\mathrm{CO}_{2} / \mathrm{Rb}$ ratios.

A critical examination of melt inclusions at Hawaii and other enriched hot spots requires knowledge of the $\mathrm{CO}_{2}$ content of ubiquitous vapor bubbles within these inclusions. We estimate that hot spot $\mathrm{CO}_{2}$ fluxes comprise $10-50 \%$ of the total MORB $\mathrm{CO}_{2}$ flux. The hot spot flux is large compared to the additional 1.5-3.0\% magma flux from hot spot volcanism, emphasizing the significant enrichment of $\mathrm{CO}_{2}$ in hot spot mantle sources compared with the MORB mantle. Our understanding of hot spot $\mathrm{CO}_{2}$ is currently limited by the lack of vapor-undersaturated melt inclusion suites; it is not yet apparent whether melts that were undersaturated at the time of entrapment will be recognized once we can precisely account for the $\mathrm{CO}_{2}$ in melt inclusion shrinkage bubbles. However, this is presently a very active area of investigation not only at hot spots, but also at arcs, and thus conclusions (one way or the other) are likely not far behind the publication of this chapter.

LIPs can deliver enormous volatile fluxes over short time periods, although their climate impact is driven by the relative balance of $\mathrm{SO}_{2}$ over shorter timescales (years to decades) versus $\mathrm{CO}_{2}$ in the longer term. The pace of volcanism and relative fluxes of volatile species from LIPs remain largely unknown. So, too, does our knowledge of mantle $\mathrm{CO}_{2}$ fluxes going back in time. 
Mantle carbon can, in its oxidized form, lower the solidus of silicates and generate mantle melts. At great depths in the mantle, $f_{2}$ is likely low enough to stabilize reduced forms of carbon that do not facilitate silicate melting. The shallow reaches of the upper mantle, however, are everywhere sufficiently oxidizing that carbonate is the stable phase. Thus, at some point during adiabatic ascent, the oxidation of carbon will initiate melting, and large variations in the $\mathrm{CO}_{2}$ content of the mantle will translate into variations in the melt fraction that may be observable by geophysical methods. In the future, large-scale geophysical experiments involving both seismic and electromagnetic studies at $\mathrm{CO}_{2}$ depleted and $\mathrm{CO}_{2}$-enriched ridge segments could reveal whether a redox-melting boundary exists in the sub-ridge mantle. At the same time, improved understanding of the variation of $f \mathrm{O}_{2}$ with depth in the convecting mantle should provide further tests of the behavior of the upper mantle in regions where melting is expected.

\section{Acknowledgments}

Erik Hauri worked relentlessly on this contribution, and many associated contributions, in the months, and even in the days, before he passed. We, his coauthors, dedicate this chapter to Erik - to his scientific vision, his insights, his magnificent data, his leadership, his spirit of discovery, his mentorship, and his friendship. We miss him terribly.

Many thanks to Jianhua Wang for expert assistance negotiating with cranky instruments in the Carnegie SIMS lab, to the Smithsonian Department of Mineral Sciences for assistance with sample preparation, to Mike Garcia and Aaron Pietruszka for provision of submarine Hawaii samples, and to Frank Trusdell and Jim Kauahikaua of the Hawaii Volcano Observatory (HVO) for going above and beyond the call of duty in making possible our sampling of Hawaiian cinder cones. We thank the geochemistry group at IPGP, University of Paris, for sharing data and samples from the Pacific-Antarctic Ridge, and the captain, crew, and scientific parties of the PACANTARCTIC 1 and 2 cruises (PAR), the GIMNAUT, CD127, and KNOX11RR cruises (CIR), the PROTEA-5, MD34, AG22, and AG53 cruises (SWIR), and the CHEPR and PANORAMA-1 cruises (EPR). We also acknowledge support from the University of California Ship Funds, and NSF grant OCE-0726573 (DRH). Conversations with Mark Behn, Pierre Cartigny, Raj Dasgupta, Marc Hirschmann, Peter van Keken, Peter Kelemen, Charles Langmuir, Terry Plank, Tobias Keller, and Richard Katz have all led to improvements in this manuscript. We thank Josh Wood for drafting Figure 9.1 and Glenn Macpherson for the Kilauea Iki melt inclusion photograph. We benefited from thorough and constructive reviews from Simon Matthews and Cyril Aubaud and from Raj Dasgupta's editorial handling. This is a contribution to the Deep Carbon Observatory.

\section{Questions for the Classroom}

1 This chapter puts forth a methodology for quantifying global fluxes based on the assumption that $\mathrm{CO}_{2} / \mathrm{Ba}$ and $\mathrm{CO}_{2} / \mathrm{Rb}$ ratios are constant in Earth's mantle. What 
processes might fractionate these ratios? How might the hypothesis that these ratios are relatively invariant be tested?

2 Other than identifying sample suites with constant $\mathrm{CO}_{2} / \mathrm{Ba}$ or $\mathrm{CO}_{2} / \mathrm{Rb}$ ratios, are there other ways to test whether samples have experienced pre-eruptive degassing?

3 How could new, promising samples to determine mantle carbon concentrations be discovered?

4 What factors limit our ability quantify the amount of carbon stored in the mantle?

5 What factors limit our ability to quantify the flux of carbon out of the mantle?

6 From the current mid-ocean ridge outgassing rate, how long is required to accumulate the mass of carbon in the crust, ocean, and atmosphere $\left(\sim 1 \times 10^{23} \mathrm{~g} \mathrm{C}\right)$ ? How would this number change if carbon is returned to the mantle in subduction zones?

7 How might the carbon outgassing rate from mid-ocean ridges and hot spots have changed throughout Earth's history?

8 Use the batch melting equation (9.2) to calculate the $\mathrm{CO}_{2}$ and $\mathrm{Ba}$ concentrations and $\mathrm{CO}_{2} / \mathrm{Ba}$ ratio of partial melts formed by melting a mantle with $100 \mathrm{ppm} \mathrm{CO}_{2}$ and $1 \mathrm{ppm} \mathrm{Ba}$ (using peridotite-melt partition coefficients of 0.00055 and 0.00012 for $\mathrm{CO}_{2}$ and $\mathrm{Ba}$, respectively, and varying the degree of melting from $0 \%$ to $20 \%$ ). At what degree of melting does the $\mathrm{CO}_{2} / \mathrm{Ba}$ ratio of the partial melt equal to that of the mantle source (100)? What can this tell us about the usefulness of $\mathrm{CO}_{2} / \mathrm{Ba}$ ratios measured in mid-ocean ridges and OIBs?

9 Look at the variation of other volatile species included in this chapter $\left(\mathrm{H}_{2} \mathrm{O}, \mathrm{Cl}, \mathrm{F}\right.$, or $\mathrm{S})$. How do they vary as a function of major elements, as a function of incompatible trace elements, and as a function of location along the ridge system? How do these trends differ from those of $\mathrm{CO}_{2}$ ? How is their solubility in basalt different from $\mathrm{CO}_{2}$ ?

10 Given the potential for carbon to precipitate on melt inclusion bubble walls and thus be missed by quantification with Raman spectroscopy, what is the future promise of quantifying $\mathrm{CO}_{2}$ in melt inclusions that have nucleated bubbles?

\section{References}

1. Zhong, Y. et al., Centennial-scale climate change from decadally-paced explosive volcanism: a coupled sea ice-ocean mechanism. Clim. Dyn. 37, 2373-2387 (2010).

2. Robock, A., Volcanic eruptions and climate. Rev. Geophys. 38, 191-219 (2000).

3. Shindell, D.T., Volcanic and solar forcing of climate change during the preindustrial era. J. Climate 16, 4094-4107 (2003).

4. Huybers, P. \& Langmuir, C.H., Delayed CO- emissions from mid-ocean ridge volcanism as a possible cause of late-Pleistocene glacial cycles. Earth Planet. Sci. Lett. 457, 238-249 (2017).

5. Halliday, A.N., The origins of volatiles in the terrestrial planets. Geochim. Cosmochim. Acta 105, 146-171 (2013).

6. Hirschmann, M.M., Comparative deep Earth volatile cycles: the case for $\mathrm{C}$ recycling from exosphere/mantle fractionation of major $\left(\mathrm{H}_{2} \mathrm{O}, \mathrm{C}, \mathrm{N}\right)$ volatiles and from $\mathrm{H}_{2} \mathrm{O}$ / 
$\mathrm{Ce}, \mathrm{CO}_{2} / \mathrm{Ba}$, and $\mathrm{CO}_{2} / \mathrm{Nb}$ exosphere ratios. Earth Planet. Sci. Lett. 502, 262-273 (2018).

7. Dasgupta, R. \& Hirschmann, M.M., The deep carbon cycle and melting in Earth's interior. Earth Planet. Sci. Lett. 298, 1-13 (2010).

8. Kelemen, P.B. \& Manning, C.E., Reevaluating carbon fluxes in subduction zones, what goes down, mostly comes up. Proc. Natl Acad. Sci. 112, E3997-E4006 (2015).

9. Marty, B., Alexander, C.M.O.D., \& Raymond, S.N., Primordial origins of Earth's carbon. Rev. Mineral. Geochem. 75, 149-181 (2013).

10. Marty, B. \& Tolstikhin, I.N., $\mathrm{CO}_{2}$ fluxes from mid-ocean ridges, arcs and plumes. Chem. Geol. 145, 233-248 (1998).

11. Crisp, J.A., Rates of magma emplacement and volcanic output. J. Volcan. Geotherm. Res. 20, 177-211 (1984).

12. Schoene, B., Guex, J., Bartolini, A., Schaltegger, U., \& Blackburn, T.J., Correlating the end-Triassic mass extinction and flood basalt volcanism at the $100 \mathrm{ka}$ level. Geology 38, 387-390 (2010).

13. Chung, S., Jahn, B.M., Wu, G.Y., Lo, C.H., \& Cong, B.L., The Emeishan flood basant in SW China: a mantle plume initiation model and its connection with continental breakup and mass extinction at the Permian-Triassic boundary, in Mantle Dynamics and Plate Interactions in East Asia: American Geophysical Union Geodynamics Monograph 27, eds. M.F.J. Flower, S.-L. Chung, C.-H. Lo, \& T.-Y. Lee (American Geophysical Union, Washington, DC, 1998), pp. 47-58.

14. Kamo, S.L. et al., Rapid eruption of Siberian flood-volcanic rocks and evidence for coincidence with the Permian-Triassic boundary and mass extinction at $251 \mathrm{Ma}$. Earth Planet. Sci. Lett. 214, 75-91 (2003).

15. Marzoli, A. et al., Extensive 200-million-year-old continental flood basalts of the Central Atlantic Magmatic Province. Science 284, 616-618 (1999).

16. Self, S., Widdowson, M., Thordarson, T., \& Jay, A.E., Volatile fluxes during flood basalt eruptions and potential effects on the global environment: a Deccan perspective. Earth Planet. Sci. Lett. 248, 518-532 (2006).

17. Gale, A., Langmuir, C.H., \& Dalton, C.A., The global systematics of ocean ridge basalts and their origin. J. Petrol. 55, 1051-1082 (2014).

18. Kelley, K.A., Kingsley, R., \& Schilling, J.-G., Composition of plume-influenced mid-ocean ridge lavas and glasses from the Mid-Atlantic Ridge, East Pacific Rise, Galapagos Spreading Center, and Gulf of Aden. Geochem. Geophys. Geosyst. 14, 223-242 (2013).

19. Kinzler, R.J. \& Grove, T.L., Primary magmas of mid-ocean ridge basalts 1. Experiments and methods. J. Geophys. Res. Solid Earth 97, 6885-6906 (1992).

20. Klein, E.M. \& Langmuir, C.H., Global correlations of ocean ridge basalt chemistry with axial depth and crustal thickness. J. Geophys. Res. Solid Earth 92, 8089-8115 (1987).

21. Langmuir, C.H., Klein, E.M., \& Plank, T., Petrological systematics of mid-ocean ridge basalts: constraints on melt generation beneath ocean ridges, in Mantle Flow and Melt Generation at Mid-Ocean Ridges, eds. J.P. Morgan, D.K. Blackman, \& J.M. Sinton (American Geophysical Union, Washington, DC, 1992), pp. 183-280.

22. Hart, S.R., A large-scale isotope anomaly in the Southern Hemisphere mantle. Nature 309, 753-757 (1984).

23. Hofmann, A.W., Chemical differentiation of the Earth: the relationship between mantle, continental crust, and oceanic crust. Earth Planet. Sci. Lett. 90, 297-314 (1988). 
24. Stracke, A., Hofmann, A.W., \& Hart, S.R., FOZO, HIMU, and the rest of the mantle zoo. Geochem. Geophys. Geosyst. 6, Q05007 (2005).

25. Zindler, A. \& Hart, S., Chemical geodynamics. Ann. Rev. Earth Planet. Sci. 14, 493-571 (1986).

26. Horan, M.F. et al., Tracking Hadean processes in modern basalts with 142neodymium. Earth Planet. Sci. Lett. 484, 184-191 (2018).

27. Mukhopadhyay, S., Early differentiation and volatile accretion recorded in deepmantle neon and xenon. Nature 486, 101-104 (2012).

28. Mundl, A. et al., Tungsten-182 heterogeneity in modern ocean island basalts. Science 356, 66-69 (2017).

29. Parai, R., Mukhopadhyay, S., \& Standish, J.J., Heterogeneous upper mantle Ne, Ar and Xe isotopic compositions and a possibble Dupal noble gas signature recorded in basalts from the Southwest Indian Ridge. Earth Planet. Sci. Lett. 359-360, 227-239 (2012).

30. Peters, B.J., Carlson, R.W., Day, J.M.D., \& Horan, M.F., Hadean silicate differentiation preserved by anomalous ${ }^{142} \mathrm{Nd} /{ }^{144} \mathrm{Nd}$ ratios in the Réunion hotspot source. Nature 555, 89-93 (2018).

31. Peto, M.K., Mukhopadhyay, S., \& Kelley, K.A., Heterogeneities from the first 100 million years recorded in deep mantle noble gases from the Northern Lau Back-arc Basin. Earth Planet. Sci. Lett. 369, 13-23 (2013).

32. Rizo, H. et al., Preservation of Earth-forming events in the tungsten isotopic composition of modern flood basalts. Science 352, 809-812 (2016).

33. Tucker, J.M., Mukhopadhyay, S., \& Schilling, J.-G., The heavy noble gas composition of the depleted MORB mantle (DMM) and its implications for the preservation of heterogeneities in the mantle. Earth Planet. Sci. Lett. 355-356, 244-254 (2012).

34. Donnelly, K.E., Goldstein, S.L., Langmuir, C.H., \& Spiegelman, M., Origin of enriched ocean ridge basalts and implications for mantle dynamics. Earth Planet. Sci. Lett. 226, 347-366 (2004).

35. Schilling, J.G. et al., Petrologic and geochemical variations along the Mid-Atlantic Ridge from $29^{\circ} \mathrm{N}$ to $73^{\circ} \mathrm{N}$. Am. J. Sci. 283, 510-586 (1983).

36. Gale, A., Dalton, C.A., Langmuir, C.H., Su, Y., \& Schilling, J.-G., The mean composition of ocean ridge basalts. Geochem. Geophys. Geosyst. 14, 489-518 (2013).

37. Dixon, J.E. \& Stolper, E.M., An experimental study of water and carbon dioxide solubilities in mid-ocean ridge basaltic liquids. Part II: applications to degassing. $J$. Petrol. 36, 1633-1646 (1995).

38. Javoy, M. \& Pineau, F., The volatiles record of a popping rock from the Mid-Atlantic Ridge at $14^{\circ} \mathrm{N}$ : chemical and isotopic composition of gas trapped in the vesicles. Earth Planet. Sci. Lett. 107, 598-611 (1991).

39. Dixon, J.E., Stolper, E.M., \& Holloway, J.R., An experimental study of water and carbon dioxide solubilities in mid-ocean ridge basaltic liquids. Part I: calibration and solubility models. J. Petrol. 36, 1607-1631 (1995).

40. Jendrzejewski, N., Trull, T.W., Pineau, F., \& Javoy, M., Carbon solubility in midocean ridge basaltic melt at low pressures (250-1950 bar). Chem. Geol. 138, 81-92 (1997).

41. Pan, V., Holloway, J.R., \& Hervig, R.L., The temperature and pressure dependence of carbon dioxide solubility in tholeiitic basalt. Geochim. Cosmochim. Acta 55, 1587-1595 (1991). 
42. Shishkina, T.A., Botcharnikov, R.E., Holtz, F., Almeev, R.R., \& Portnyagin, M.V., Solubility of $\mathrm{H}_{2} \mathrm{O}$ - and $\mathrm{CO}_{2}$-bearing fluids in tholeiitic basalts at pressures up to 500MPa. Chem. Geol. 277, 115-125 (2010).

43. Aster, E.M. et al., Reconstructing $\mathrm{CO}_{2}$ concentrations in basaltic melt inclusions using Raman analysis of vapor bubbles. J. Volcan. Geotherm. Res. 323, 148-162 (2016).

44. Moore, L.R. et al., Bubbles matter: an assessment of the contribution of vapor bubbles to melt inclusion volatile budgets. Am. Mineral. 100, 806-823 (2015).

45. Hirano, N. et al., Volcanism in response to plate flexure. Science 313, 1426-1428 (2006).

46. Curators of Marine and Lacustrine Geological Samples Consortium. The Index to Marine and Lacustrine Geological Samples (IMLGS). NOAA National Centers for Environmental Information. https://data.nodc.noaa.gov/cgi-bin/iso?id=gov.noaa .ngdc.mgg.geology:G00028.

47. Le Voyer, M. et al., Carbon fluxes and primary magma $\mathrm{CO}_{2}$ contents along the global mid-ocean ridge system. Geochem. Geophys. Geosyst. 20, 1387-1424 (2019).

48. Cartigny, P., Pineau, F., Aubaud, C., \& Javoy, M., Towards a consistent mantle carbon flux estimate: insights from volatile systematics $\left(\mathrm{H}_{2} \mathrm{O} / \mathrm{Ce}, \mathrm{dD}, \mathrm{CO}_{2} / \mathrm{Nb}\right)$ in the North Atlantic mantle $\left(14^{\circ} \mathrm{N}\right.$ and $\left.34^{\circ} \mathrm{N}\right)$. Earth Planet. Sci. Lett. 265, 672-685 (2008).

49. Saal, A.E., Hauri, E.H., Langmuir, C.H., \& Perfit, M.R., Vapour undersaturation in primitive mid-ocean-ridge basalt and the volatile content of Earth's upper mantle. Nature 419, 451-455 (2002).

50. Michael, P.J. \& Graham, D.W., The behavior and concentration of $\mathrm{CO}_{2}$ in the suboceanic mantle: inferences from undegassed ocean ridge and ocean island basalts. Lithos 236-237, 338-351 (2015).

51. Shimizu, K. et al., Two-component mantle melting-mixing model for the generation of mid-ocean ridge basalts: implications for the volatile content of the Pacific upper mantle. Geochim. Cosmochim. Acta 176, 44-80 (2016).

52. Le Voyer, M., Kelley, K.A., Cottrell, E., \& Hauri, E.H., Heterogeneity in mantle carbon content from $\mathrm{CO}_{2}$-undersaturated basalts. Nat. Commun. 8, 14062 (2017).

53. Hauri, E.H. et al., $\mathrm{CO}_{2}$ content beneath northern Iceland and the variability of mantle carbon. Geology 46, 55-58 (2017).

54. Shaw, A.M., Behn, M.D., Humphris, S.E., Sohn, R.A., \& Gregg, P.M., Deep pooling of low degree melts and volatile fluxes at the $85^{\circ} \mathrm{E}$ segment of the Gakkel Ridge: evidence from olivine-hosted melt inclusions and glasses. Earth Planet. Sci. Lett. 289, 311-322 (2010).

55. Wanless, V.D., Behn, M.D., Shaw, A.M., \& Plank, T., Variations in melting dynamics and mantle compositions along the Eastern Volcanic Zone of the Gakkel Ridge: insights from olivine-hosted melt inclusions. Contrib. Mineral. Petrol. 167, 1005-1027 (2014).

56. Wanless, V.D. \& Shaw, A.M., Lower crustal crystallization and melt evolution at mid-ocean ridges. Nat. Geosci. 5, 651-655 (2012).

57. Wanless, V.D. et al., Magmatic plumbing at Lucky Strike volcano based on olivinehosted melt inclusion compositions. Geochem. Geophys. Geosyst. 16, 126-147 (2015).

58. Helo, C., Longpré, M.-A., Shimizu, N., Clague, D.A., \& Stix, J., Explosive eruptions at mid-ocean ridges driven by $\mathrm{CO}_{2}$-rich magmas. Nat. Geosci. 4, 260-263 (2011). 
59. Le Voyer, M. et al., Volatile abundances in MORB magmas along the global midocean ridge system (2018). Interdisciplinary Earth Data Alliance. doi:10.1594/IEDA/ 111195.

60. Marske, J.P. \& Hauri, E.H., Major- and trace-element compositions of 915 melt inclusions and host olivines from Hawaiian shield volcanoes. (2019). Interdisciplinary Earth Data Alliance. doi:10.1594/IEDA/111193.

61. Tucker, J.M. et al., A high carbon content of the Hawaiian mantle from olivinehosted melt inclusions. Geochim. Cosmochim. Acta 254, 156-172 (2019).

62. Métrich, N. et al., Is the "Azores Hotspot" a wetspot? Insights from the geochemistry of fluid and melt inclusions in olivine of Pico basalts. J. Petrol. 55, 377-393 (2014).

63. Longpré, M.-A., Stix, J., Klügel, A., \& Shimizu, N., Mantle to surface degassing of carbon- and sulphur-rich alkaline magma at El Hierro, Canary Islands. Earth Planet. Sci. Lett. 460, 268-280 (2017).

64. Hartley, M.E., Maclennan, J., Edmonds, M., \& Thordarson, T., Reconstructing the deep $\mathrm{CO}_{2}$ degassing behaviour of large basaltic fissure eruptions. Earth Planet. Sci. Lett. 393, 120-131 (2014).

65. Neave, D.A., Maclennan, J., Edmonds, M., \& Thordarson, T., Melt mixing causes negative correlation of trace element enrichment and $\mathrm{CO}_{2}$ content prior to an Icelandic eruption. Earth Planet. Sci. Lett. 400, 272-283 (2014).

66. Tucker, J.M., Shrinkage bubble $\mathrm{CO}_{2}$ reconstructions from ocean island basalt melt inclusions. Interdiscip. Earth Data Alliance (2019). doi:10.1594/IEDA/111230.

67. Dixon, J.E., Stolper, E.M., \& Delaney, J.R., Infrared spectroscopic measurements of $\mathrm{CO}_{2}$ and $\mathrm{H}_{2} \mathrm{O}$ in Juan de Fuca Ridge basaltic glasses. Earth Planet. Sci. Lett. 90, 87-104 (1988).

68. Le Roux, P.J., Shirey, S.B., Hauri, E.H., \& Perfit, M.R., The effects of variable sources, processes and contaminants on the composition of northern EPR MORB $\left(8-10^{\circ} \mathrm{N}\right.$ and $\left.12-14^{\circ} \mathrm{N}\right)$ : evidence from volatiles $\left(\mathrm{H}_{2} \mathrm{O}, \mathrm{CO}_{2}, \mathrm{~S}\right)$ and halogens $(\mathrm{F}, \mathrm{Cl})$. Earth Planet. Sci. Lett. 251, 209-231 (2006).

69. Chavrit, D., Humler, E., Morizet, Y., \& Laporte, D., Influence of magma ascent rate on carbon dioxide degassing at oceanic ridges: message in a bubble. Earth Planet. Sci. Lett. 357-358, 376-385 (2012).

70. Papale, P., Moretti, R., \& Barbato, D., The compositional dependence of the saturation surface of $\mathrm{H}_{2} \mathrm{O}+\mathrm{CO}_{2}$ fluids in silicate melts. Chem. Geol. 229, 78-95 (2006).

71. Ghiorso, M.S. \& Gualda, G.A.R., An $\mathrm{H}_{2} \mathrm{O}-\mathrm{CO}_{2}$ mixed fluid saturation model compatible with rhyolite-MELTS. Contrib. Mineral. Petrol. 169, 53 (2015).

72. Craig, H., Clarke, W.B., \& Beg, M.A., Excess ${ }^{3} \mathrm{He}$ in deep water on the East Pacific Rise. Earth Planet. Sci. Lett. 26, 125-132 (1975).

73. Schlitzer, R., Quantifying He fluxes from the mantle using multi-tracer data assimilation. Philos. Trans. R. Soc. A 374, 20150288 (2016).

74. Holzer, M. et al., Objective estimates of mantle ${ }^{3} \mathrm{He}$ in the ocean and implications for constraining the deep ocean circulation. Earth Planet. Sci. Lett. 485, 305-314 (2017).

75. Tucker, J.M., Mukhopadhyay, S., \& Gonnermann, H.M., Reconstructing mantle carbon and noble gas contents from degassed mid-ocean ridge basalts. Earth Planet. Sci. Lett. 496, 108-119 (2018).

76. Burnard, P., Correction for volatile fractionation in ascending magmas: noble gas abundances in primary mantle melts. Geochim. Cosmochim. Acta 65, 2605-2614 (2001). 
77. Colin, A., Burnard, P., \& Marty, B., Mechanisms of magma degassing at midoceanic ridges and the local volatile composition $\left({ }^{4} \mathrm{He}-{ }^{40} \mathrm{Ar} *-\mathrm{CO}_{2}\right)$ of the mantle by laser ablation analysis of individual MORB vesicles. Earth Planet. Sci. Lett. 361, 183-194 (2013).

78. Rosenthal, A., Hauri, E., \& Hirschmann, M., Experimental determination of C, F, and $\mathrm{H}$ partitioning between mantle minerals and carbonated basalt, $\mathrm{CO}_{2} / \mathrm{Ba}$ and $\mathrm{CO}_{2} /$ $\mathrm{Nb}$ systematics of partial melting, and the $\mathrm{CO}_{2}$ contents of basaltic source regions. Earth Planet. Sci. Lett. 412, 77-87 (2015).

79. Matthews, S., Shorttle, O., Rudge, J.F., \& Maclennan, J., Constraining mantle carbon: $\mathrm{CO}_{2}$-trace element systematics in basalts and the roles of magma mixing and degassing. Earth Planet. Sci. Lett. 480, 1-14 (2017).

80. Shimizu, K., Saal, A.E., Hauri, E.H., Perfit, M.R., \& Hékinian, R., Evaluating the roles of melt-rock interaction and partial degassing on the $\mathrm{CO}_{2} / \mathrm{Ba}$ ratios of MORB: implications for the $\mathrm{CO}_{2}$ budget in Earth's depleted upper mantle, Geochim. Cosmochim. Acta. (2019) (submitted).

81. Koornneef, J.M. et al., TIMS analysis of $\mathrm{Sr}$ and $\mathrm{Nd}$ isotopes in melt inclusions from Italian potassium-rich lavas using prototype $10^{13} \Omega$ amplifiers. Chem. Geol. 397, 14-23 (2015).

82. Maclennan, J., Lead isotope variability in olivine-hosted melt inclusions from Iceland. Geochim. Cosmochim. Acta 72, 4159-4176 (2008).

83. Paul, B. et al., Melt inclusion Pb-isotope analysis by LA-MC-ICPMS: assessment of analytical performance and application to OIB genesis. Chem. Geol. 289, 210-223 (2011).

84. Saal, A.E. et al., Pb isotopic variability in melt inclusions from the EMI-EMIIHIMU mantle end-members and the role of the oceanic lithosphere. Earth Planet. Sci. Lett. 240, 605-620 (2005).

85. Dupré, B. \& Allégre, C.J., $\mathrm{Pb}-\mathrm{Sr}$ isotope variation in Indian Ocean basalts and mixing phenomena. Nature 303, 142 (1983).

86. Niu, Y.L., Collerson, K.D., Batiza, R., Wendt, J.L., \& Regelous, M., Origin of enriched-type mid-ocean ridge basalts at ridges far from mantle plumes: the East Pacific Rise at $11^{\circ} 20^{\prime}$ N. J. Geophys. Res. 104, 7067-7087 (1999).

87. Arevalo Jr, R. \& McDonough, W.F., Chemical variations and regional diversity observed in MORB. Chem. Geol. 271, 70-85 (2010).

88. Behn, M.D. \& Grove, T.L., Melting systematics in mid-ocean ridge basalts: application of a plagioclase-spinel melting model to global variations in major element chemistry and crustal thickness. J. Geophys. Res. Solid Earth 120, 4863-4886 (2015).

89. White, R.S., McKenzie, D., \& O’Nions, R.K., Oceanic crustal thickness from seismic measurements and rare earth element inversions. J. Geophys. Res. Solid Earth 97, 19683-19715 (1992).

90. DeMets, C., Gordon, R.G., Argus, D.F., \& Stein, S., Effect of recent revisions to the geomagnetic reversal time scale on estimates of current plate motions. J. Geophys. Res. 21, 2191-2194 (1994).

91. Asimow, P.D., Hirschmann, M.M., \& Stolper, E.M., Calculation of peridotite partial melting from thermodynamic models of minerals and melts, IV. Adiabatic decompression and the composition and mean properties of mid-ocean ridge basalts. J. Petrol. 42, 963-998 (2001). 
92. Van Avendonk, H.J.A., Davis, J.K., Harding, J.L., \& Lawver, L.A., Decrease in oceanic crustal thickness since the breakup of Pangaea. Nat. Geosci. 10, 58-61 (2016).

93. Broecker, W.S. \& Peng, T.-H., Carbon cycle: 1985 glacial to interglacial changes in the operation of the global carbon cycle. Radiocarbon 28, 309-327 (1986).

94. Alt, J.C. \& Shanks, W.C., Serpentinization of abyssal peridotites from the MARK area, Mid-Atlantic Ridge: sulfur geochemistry and reaction modeling. Geochim. Cosmochim. Acta 67, 641-653 (2003).

95. Alt, J.C. \& Teagle, D., The uptake of carbon during alteration of ocean crust. Geochim. Cosmochim. Acta 63, 1527-1535 (1999).

96. Hayes, J.M. \& Waldbauer, J.R., The carbon cycle and associated redox processes through time. Philos. Trans. R. Soc. Lond. B Biol. Sci. 361, 931-950 (2006).

97. French, S.W. \& Romanowicz, B., Broad plumes rooted at the base of the Earth's mantle beneath major hotspots. Nature 525, 95-99 (2015).

98. Montelli, R., Nolet, G., Dahlen, F.A., \& Masters, G., A catalogue of deep mantle plumes: new results from finite-frequency tomography. Geochem. Geophys. Geosyst. 7, Q11007 (2006).

99. Burton, M.R., Sawyer, G.M., \& Granieri, D., Deep carbon emissions from volcanoes. Rev. Mineral. Geochem. 75, 323-354 (2013).

100. Richards, M.A., Duncan, R.A., \& Courtillot, V.E., Flood basalts and hot-spot tracks: plume heads and tails. Science 246, 103-107 (1989).

101. Kiehl, J.T. \& Shields, C.A., Climate simulation of the latest Permian: implications for mass extinction. Geology 33, 757-760 (2005).

102. Sleep, N.H., Hotspots and mantle plumes: some phenomenology. J. Geophys. Res. 95, 6715-6736 (1990).

103. Davies, G.F., Ocean bathymetry and mantle convection: 1. Large-scale flow and hotspots. J. Geophys. Res. 93, 10467-10480 (1988).

104. Dixon, J.E. \& Clague, D.A., Volatiles in basaltic glasses from Loihi seamount, Hawaii: evidence for a relatively dry plume component. J. Petrol. 42, 627-654 (2001).

105. Dixon, J.E., Clague, D.A., Wallace, P., \& Poreda, R., Volatiles in alkalic basalts from the North Arch volcanic field, Hawaii: extensive degassing of deep submarineerupted alkalic series lavas. J. Petrol. 38, 911-939 (1997).

106. Simons, K., Dixon, J.E., Schilling, J.-G., Kingsley, R., \& Poreda, R., Volatiles in basaltic glasses from the Easter-Salas y Gomez Seamount Chain and Easter Microplate: implications for geochemical cycling of volatile elements. Geochem. Geophys. Geosyst. 3, 1039 (2002).

107. Workman, R.K., Hauri, E., Hart, S.R., Wang, J., \& Blusztajn, J., Volatile and trace elements in basaltic glasses from Samoa: implications for water distribution in the mantle. Earth Planet. Sci. Lett. 241, 932-951 (2006).

108. Hilton, D.R., Thirlwall, M.F., Taylor, R.N., Murton, B.J., \& Nichols, A., Controls on magmatic degassing along the Reykjanes Ridge with implications for the helium paradox. Earth Planet. Sci. Lett. 183, 43-50 (2000).

109. Hauri, E., SIMS analysis of volatiles in silicate glasses, 2: isotopes and abundances in Hawaiian melt inclusions. Chem. Geol. 183, 115-141 (2002).

110. Edmonds, M. et al., Magma storage, transport and degassing during the 2008-10 summit eruption at Kilauea Volcano, Hawai'i. Geochim. Cosmochim. Acta 123, 284-301 (2013). 
111. Sides, I.R., Edmonds, M., MacLennan, J., Swanson, D.A., \& Houghton, B.F., Eruption style at Kilauea Volcano in Hawai i linked to primary melt composition. Nat. Geosci. 7, 1-6 (2014).

112. Gonnermann, H.M. \& Mukhopadhyay, S., Non-equilibrium degassing and a primordial source for helium in ocean-island basalts. Nature 449, 1037-1040 (2007).

113. Anderson, K.R. \& Poland, M.P., Abundant carbon in the mantle beneath Hawai'i. Nat. Geosci. 10, 704-708 (2017).

114. Gerlach, T.M., McGee, K.A., Elias, T., Sutton, A.J., \& Doukas, M.P., Carbon dioxide emission rate of Kilauea Volcano: implications for primary magma and the summit reservoir. J. Geophys. Res. 107, ECV 3-1-ECV 3-15 (2002).

115. Poland, M.P., Miklius, A., Sutton, A.J., \& Thornber, C.R., A mantle-driven surge in magma supply to Kîlauea Volcano during 2003-2007. Nat. Geosci. 5, 295-300 (2012).

116. Aubaud, C., Pineau, F., Hekinian, R., \& Javoy, M., Carbon and hydrogen isotope constraints on degassing of $\mathrm{CO}_{2}$ and $\mathrm{H}_{2} \mathrm{O}$ in submarine lavas from the Pitcairn hotspot (South Pacific). Geophys. Res. Lett. 33, L02308 (2006).

117. Aubaud, C., Pineau, F., Hekinian, R., \& Javoy, M., Degassing of $\mathrm{CO}_{2}$ and $\mathrm{H}_{2} \mathrm{O}$ in submarine lavas from the Society hotspot. Earth Planet. Sci. Lett. 235, 511-527 (2005).

118. Batiza, R., Abundances, distribution and sizes of volcanoes in the Pacific Ocean and implications for the origin of non-hotspot volcanoes. Earth Planet. Sci. Lett. 60, 195-206 (1982).

119. Wessel, P. \& Lyons, S., Distribution of large Pacific seamounts from Geosat/ERS-1: implications for the history of intraplate volcanism. J. Geophys. Res. Solid Earth 102, 22459-22475 (1997).

120. Kim, S.-S. \& Wessel, P., New global seamount census from altimetry-derived gravity data. Geophys. J. Int. 186, 615-631 (2011).

121. Black, B.A., Hauri, E.H., Elkins-Tanton, L.T., \& Brown, S.M., Sulfur isotopic evidence for sources of volatiles in Siberian Traps magmas. Earth Planet. Sci. Lett. 394, 58-69 (2014).

122. Black, B.A. \& Manga, M., Volatiles and the tempo of flood basalt magmatism. Earth Planet. Sci. Lett. 458, 130-140 (2017).

123. Coffin, M.F. \& Eldholm, O., Scratching the surface: estimating dimensions of large igneous provinces. Geology 21, 515-518 (1993).

124. Courtillot, V.E. \& Renne, P.R., On the ages of flood basalt events. Comp. Rend. Geosci. 335, 113-140 (2003).

125. Ernst, R.E., Large mafic magmatic events through time and links to mantle-plume heads, in Mantle Plumes: Their Identification through Time, eds. R.E. Ernst \& K.L. Buchan (Geological Society of America Special Paper, Boulder, CO, 2001), p. 483.

126. Ward, P.L., Sulfur dioxide initiates global climate change in four ways. Thin Solid Films 517, 3188-3203 (2009).

127. Sleep, N.H., Hotspots and mantle plumes. Ann. Rev. Earth Planet. Sci. 20, 19-43 (1992).

128. Davies, G.F. \& Richards, M.A., Mantle convection. J. Geol. 100, 151-206 (1992).

129. Norman, M.D. \& Garcia, M.O., Primitive magmas and source characteristics of the Hawaiian plume: petrology and geochemistry of shield picrites. Earth Planet. Sci. Lett. 168, 27-44 (1999).

130. Pietruszka, A.J., Norman, M.D., Garcia, M.O., Marske, J.P., \& Burns, D.H., Chemical heterogeneity in the Hawaiian mantle plume from the alteration and dehydration of recycled oceanic crust. Earth Planet. Sci. Lett. 361, 198-309 (2013). 
131. Barry, P.H., Hilton, D.R., Füri, E., Halldórsson, S.A., \& Grönvold, K., Carbon isotope and abundance systematics, and $\mathrm{CO}_{2}$ fluxes from Icelandic geothermal gases, fluids and subglacial basalts. Geochim. Cosmochim. Acta 134, 74-99 (2014).

132. Dasgupta, R. \& Hirschmann, M.M., Melting in the Earth's deep upper mantle caused by carbon dioxide. Nature 440, 659-662 (2006).

133. Keller, T., Katz, R.F., \& Hirschmann, M.M., Volatiles beneath mid-ocean ridges: deep melting, channelised transport, focusing, and matasomatism. Earth Planet. Sci. Lett. 464, 55-68 (2017).

134. Hirschmann, M.M., Mantle solidus: experimental constraints and the effects of peridotite composition. Geochem. Geophys. Geosyst. 1, 2000GC000070 (2000).

135. Dalton, J.A. \& Presnall, D.C., Carbonatitic melts along the solidus of model lherzolite in the system $\mathrm{CaO}-\mathrm{MgO}-\mathrm{Al}_{2} \mathrm{O}_{3}-\mathrm{SiO}_{2}-\mathrm{CO}_{2}$ from 3 to $7 \mathrm{GPa}$. Contrib. Mineral. Petrol. 131, 123-135 (1998).

136. Asimow, P.D. \& Langmuire, C.H., The importance of water to oceanic mantle melting regimes. Nature 421, 815-820 (2003).

137. Dasgupta, R. et al., Carbon-dioxide-rich silicate melt in the Earth's upper mantle. Nature 493, 211-216 (2013).

138. Dasgupta, R., Volatile-bearing partial melts beneath oceans and continents - where, how much, and of what compositions. Am. J. Sci. 318, 141-165 (2018).

139. Shcheka, S.S., Wiedenbeck, M., Frost, D.J., \& Keppler, H., Carbon solubility in mantle minerals. Earth Planet. Sci. Lett. 245, 730-742 (2006).

140. Keppler, H., Wiedenbeck, M., \& Shcheka, S.S., Carbon solubility in olivine and the mode of carbon storage in the Earth's mantle. Nature 424, 414-416 (2003).

141. Stagno, V. \& Frost, D.J., Carbon speciation in the asthenosphere: experimental measurements of the redox conditions at which carbonate-bearing melts coexist with graphite or diamond in peridotite assemblages. Earth Planet. Sci. Lett. 300, 72-84 (2010).

142. Frost, D.J. \& McCammon, C.A., The redox state of Earth's mantle. Ann. Rev. Earth Planet. Sci. 36, 389-420 (2008).

143. Luth, R.W., Carbon and carbonates in the mantle, in Mantle Petrology: Field Observations and High Pressure Experimentation: A Tribute to Francis R. (Joe) Boyd, eds. Y. Fei, C.M. Bertka, \& B.O. Mysen (Geochemical Society, Houston, TX, 1999), pp. 297-316.

144. Zhang, Z., Hastings, P., Von der Handt, A., \& Hirschmann, M.M., Experimental determination of carbon solubility in $\mathrm{Fe}-\mathrm{Ni}-\mathrm{S}$ melts. Geochim. Cosmochim. Acta 225, 66-79 (2018).

145. Armstrong, L.S., Hirschmann, M.M., Stanley, B.D., Falksen, E.G., \& Jacobsen, S.D., Speciation and solubility of reduced $\mathrm{C}-\mathrm{O}-\mathrm{H}-\mathrm{N}$ volatiles in mafic melt: implications for volcanism, atmospheric evolution, and deep volatile cycles in the terrestrial planets. Geochim. Cosmochim. Acta 171, 283-302 (2015).

146. Rohrbach, A. \& Schmidt, M.W., Redox freezing and melting in the Earth's deep mantle resulting from carbon-iron redox coupling. Nature 472, 209-212 (2011).

147. Tsuno, K. \& Dasgupta, R., Fe-Ni-Cu-C-S phase relations at high pressures and temperatures - the role of sulfur in carbon storage and diamond stability at mid- to deep-upper mantle. Earth Planet. Sci. Lett. 412, 132-142 (2015).

148. Eggler, D.H. \& Baker, D.R., Reduced volatiles in system C-O-H: implications to mantle melting, fluid formation and diamond genesis, in High-Pressure Research in Geophysics, eds. S. Akimoto \& M.H. Manghnani (Springer, New York, 1982), pp. 237-250. 
149. Eggler, D.H., Does $\mathrm{CO}_{2}$ cause partial melting in low-velocity layer of mantle. Geology 4, 69-72 (1976).

150. Dasgupta, R., Hirschmann, M.M., \& Withers, A.C., Deep global cycling of carbon constrained by the solidus of anhydrous, carbonated eclogite under upper mantle conditions. Earth Planet. Sci. Lett. 227, 73-85 (2004).

151. Massuyeau, M., Gardés, E., Morizet, Y., \& Gaillard, F., A model for the activity of silica along the carbonatite-kimberlite-mellilitite-basanite melt compositional joint. Chem. Geol. 418, 206-216 (2015).

152. Holloway, J.R., Pan, V., \& Gudmundsson, G., High-pressure fluid-absent melting experiments in the presence of graphite; oxygen fugacity, ferric/ferrous ratio and dissolved $\mathrm{CO}_{2}$. Eur. J. Mineral. 4, 105-114 (1992).

153. Stanley, B.D., Hirschmann, M.M., \& Withers, A.C., Solubility of $\mathrm{COH}$ volatiles in graphite-saturated Martian basalts. Geochim. Cosmochim. Acta 129, 54-76 (2014).

154. Eguchi, J. \& Dasgupta, R., A $\mathrm{CO}_{2}$ solubility model for silicate melts from fluid saturation to graphite or diamond saturation. Chem. Geol. 487, 23-38 (2018).

155. Balhaus, C., Redox states of lithospheric and asthenospheric upper mantle. Contrib. Mineral. Petrol. 114, 331-348 (1993).

156. Haggerty, S.E., The redox state of planetary basalts. Geophys. Res. Lett. 5, 443-446 (1978).

157. Bezos, A. \& Humler, E., The $\mathrm{Fe}^{3+} / \Sigma \mathrm{Fe}$ ratios of MORB glasses and their implications for mantle melting. Geochim. Cosmochim. Acta 69, 711-725 (2005).

158. Cottrell, E. \& Kelley, K.A., The oxidation state of Fe in MORB glasses and the oxygen fugacity of the upper mantle. Earth Planet. Sci. Lett. 305, 270-282 (2011).

159. Zhang, H.L., Cottrell, E., Solheid, P.A., Kelley, K.A., \& Hirschmann, M.M., Determination of $\mathrm{Fe}^{3+} / \Sigma \mathrm{Fe}$ of XANES basaltic glass standards by Mössbauer spectroscopy and its application to the oxidation state of iron in MORB. Chem. Geol. 479, 166-175 (2018).

160. Birner, S.K., Cottrell, E., Warren, J.M., Kelley, K.A., \& Davis, F.A., Peridotites and basalts reveal broad congruence between two independent records of mantle $f \mathrm{O}_{2}$ despite local redox heterogeneity. Earth Planet. Sci. Lett. 494, 172-189 (2018).

161. Dasgupta, R. \& Hirschmann, M.M., Effect of variable carbonate concentration on the solidus of mantle peridotite. Am. Mineral. 92, 370-379 (2007).

162. Ghosh, S., Litasov, K., \& Ohtani, E., Phase relations and melting of carbonated peridotite between 10 and $20 \mathrm{GPa}$ : a proxy for alkali- and $\mathrm{CO}_{2}$-rich silicate melts in the deep mantle. Contrib. Mineral. Petrol. 167, 964 (2014).

163. Gudmundsson, G. \& Wood, B.J., Experimental tests of garnet peridotite oxygen barometry. Contrib. Mineral. Petrol. 119, 56-67 (1995).

164. O'Neill, H.S. et al., Ferric iron in the upper mantle and in transition zone assemblages: implications for relative oxygen fugacities in the mantle, in Evolution of the Earth and Planets, eds. E. Takahashi, R. Jeanloz, \& D. Rubie (American Geophysical Union, Washington, DC, 1993), Vol. 74, pp. 73-88.

165. Balhaus, C., Is the upper mantle metal saturated? Earth Planet. Sci. Lett. 132, 75-86 (1995).

166. Rohrbach, A. et al., Metal saturation in the upper mantle. Nature 449, 456-458 (2007).

167. Stagno, V., Ojwang, D.O., McCammon, C.A., \& Frost, D.J., The oxidation state of the mantle and the extraction of carbon from Earth's interior. Nature 493, 84-88 (2013). 
168. Minarik, W.G. \& Watson, E.B., Interconnectivity of carbonate melt at low melt fraction. Earth Planet. Sci. Lett. 133, 423-437 (1995).

169. Sarafian, E., Gaetani, G.A., Hauri, E.H., \& Sarafian, A., Experimental constraints on the damp peridotite solidus and oceanic mantle potential temperature. Science $\mathbf{3 5 5}$, 942-945 (2017).

170. Keller, T. \& Katz, R.F., The role of volatiles in reactive melt transport in the asthenosphere. J. Petrol. 57, 1073-1108 (2016).

171. Dalton, C.A., Langmuir, C.H., \& Gale, A., Geophysical and geochemical evidence for deep temperature variations beneath mid-ocean ridges. Science 344, 80-83 (2014).

172. Class, C. \& Lehnert, K., PetDB expert MORB (mid-ocean ridge basalt) compilation. EarthChem Library (2012). doi:10.1594/IEDA/100060

173. Kelemen, P.B., Yogodzinski, G.M., \& Scholl, D.W., Along-strike variation in the Aleutian island arc: genesis of high $\mathrm{Mg \#}$ andesite and implications for continental crust, in Inside the Subduction Factory. American Geophysical Union Geophysical Monograph, ed. J. Eiler (American Geophysical Union, Washington DC, 2003), Vol. 138, pp. 223-276.

174. Ghiorso, M.S., Hirschmann, M.M., Reiners, P.W., \& Kress, V.C., The pMELTS: a revision of MELTS for improved calculation of phase relations and major element partitioning related to partial melting of the mantle to $3 \mathrm{GPa}$. Geochem. Geophys. Geosyst. 3, 1-35 (2002).

175. Asimow, P.D., Dixon, J.E., \& Langmuir, C.H., A hydrous melting and fractionation model for mid ocean ridge basalts: application to the Mid Atlantic Ridge near the Azores. Geochem. Geophys. Geosyst. 5, Q01E16 (2004).

176. Smith, P.M. \& Asimow, P.D., Adiabat_1ph: a new public front-end to the MELTS, pMELTS, and pHMELTS models. Geochem. Geophys. Geosyst. 6, Q02004 (2005).

177. Workman, R.K. \& Hart, S.R., Major and trace element composition of the depleted MORB mantle (DMM). Earth Planet. Sci. Lett. 231, 53-72 (2005).

178. Rudge, J.F., Maclennan, J., \& Stracke, A., The geochemical consequences of mixing melts from a heterogeneous mantle. Geochim. Cosmochim. Acta 144, 112-143 (2013).

179. Shishkina, T.A. et al., Compositional and pressure effects on the solubility of $\mathrm{H}_{2} \mathrm{O}$ and $\mathrm{CO}_{2}$ in mafic melts. Chem. Geol. 388, 112-129 (2014).

180. White, S.M., Crisp, J.A., \& Spera, F.J., Long-term volumetric eruption rates and magma budgets. Geochem. Geophys. Geosyst. 7, Q03010 (2006).

181. Poland, M.P., Miklius, A., \& Montgomery-Brown, E.K., Magma supply, storage, and transport at shield-stage Hawaiian volcanoes. US Geol. Surv. Prof. Pap. 1801, 179-234 (2014).

182. Bowman, A.W. \& Azzalini, A., Applied Smoothing Techniques for Data Analysis, (New York: Oxford University Press Inc., 1997).

183. Cottrell, E., Kelley, K.A., Hauri, E.H., \& Le Voyer, M., Mantle Carbon Contents for Mid-Ocean Ridge Segments (2019). Interdisciplinary Earth Data Alliance. doi:10.1594/IEDA/111333.

184. O'Neill, H.S., Berry, A.J. \& Mallmann, G., The oxidation state of iron in Mid-Ocean Ridge Basaltic (MORB) glasses: Implications for their petrogenesis and oxygen fugacities. Earth Planet. Sci. Lett. 504, 152-162 (2018). 